Prepared under United States Nuclear Regulatory Commission-United States Geological Survey Interagency Agreement JCN-N6184-Assessment of the Current State of the Advanced National Seismic System

\title{
Improved Earthquake Monitoring in the Central and Eastern United States in Support of Seismic Assessments for Critical Facilities
}

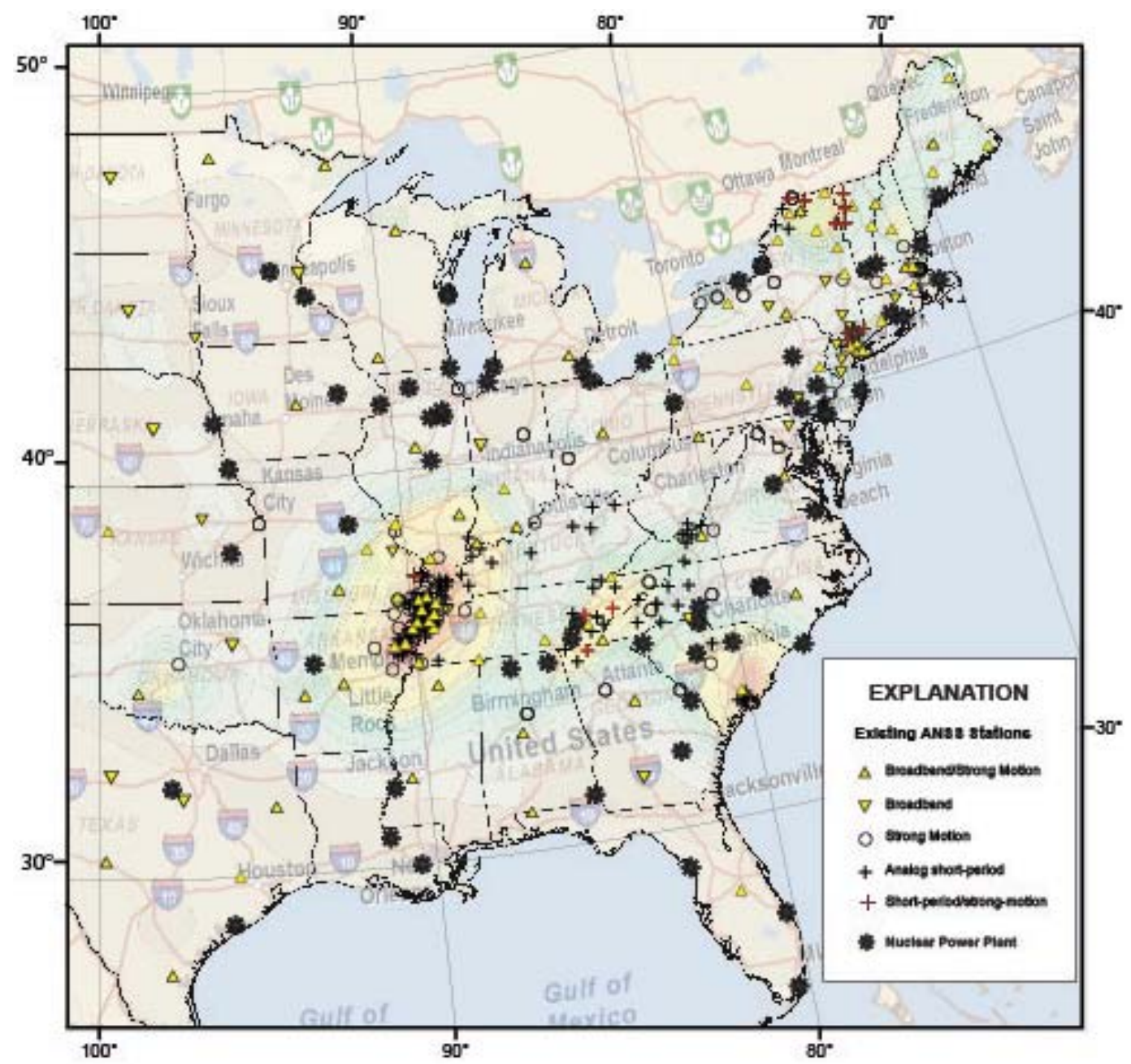

Open-File Report 2011-1101 


\section{₹USGS}

Prepared under United States Nuclear Regulatory Commission-United States Geological Survey Interagency Agreement JCN-N6184-Assessment of the Current State of the Advanced National Seismic System

\section{Improved Earthquake Monitoring in the Central and Eastern United States in Support of Seismic Assessments for Critical Facilities}

By William S. Leith, Harley M. Benz, and Robert B. Herrmann

Open-File Report 2011-1101

U.S. Department of the Interior

U.S. Geological Survey 


\section{U.S. Department of the Interior \\ KEN SALAZAR, Secretary}

U.S. Geological Survey
Marcia K. McNutt, Director

U.S. Geological Survey, Reston, Virginia: 2011

For product and ordering information:

World Wide Web: http://www.usgs.gov/pubprod

Telephone: 1-888-ASK-USGS

For more information on the USGS—-the Federal source for science about the Earth, its natural and living resources, natural hazards, and the environment:

World Wide Web: http://www.usgs.gov

Telephone: 1-888-ASK-USGS

Suggested citation:

Leith, W.S., Benz, H.M., and Herrmann, R.B., 2011, Improved earthquake monitoring in the central and eastern United States in support of seismic assessments for critical facilities: U.S. Geological Survey Open-File Report 2011-1101, 29 p.

Any use of trade, product, or firm names is for descriptive purposes only and does not imply endorsement by the U.S. Government.

Although this report is in the public domain, permission must be secured from the individual copyright owners to reproduce any copyrighted material contained within this report.

ShakeCast/ShakeMap software uses Google, Inc., imagery as a base for presentation of seismic information. Image copyright remains with Google, Inc. 


\section{Contents}

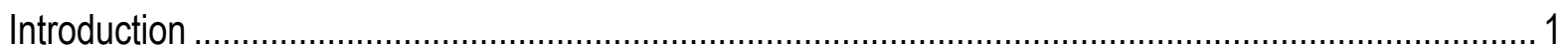

Augmentations to Regional Seismic Networks and the Advanced National Seismic System................. 2

Coordinated Station Upgrades and Infrastructure Improvements for Seismic Monitoring .................. 2 Improved Near-Source Monitoring through Coordinated Upgrades of Existing Seismographic

Stations and Infrastructure through the American Recovery and Reinvestment Act .......................... 3

Seismic Hazard in the Northeastern United States................................................................... 4

Seismic Hazard in the Southeastern United States ..................................................................

Seismic Hazard in the Central United States.......................................................................... 7

Recent Improvements to the Advanced National Seismic System and Regional Seismic Networks...7

Augmentation of Seismic Networks to Support Critical Facilities Requirements.............................. 10

Potential Strong-Motion Recording Options ......................................................................... 13

Justification for Enhanced Monitoring - Case Studies in Oklahoma and Illinois .............................. 14

Oklahoma Case Study: 2009-2010 Oklahoma Earthquake Swarm Northeast of Oklahoma City.. 14 Illinois Case Study: February 10, 2010, M 3.8 Northern Illinois Earthquake ............................... 17

Future Improvements to Advanced National Seismic System and Regional Seismic Networks........ 21

Development of Rapid Delivery of Parametric Ground-Motion Data................................................ 21

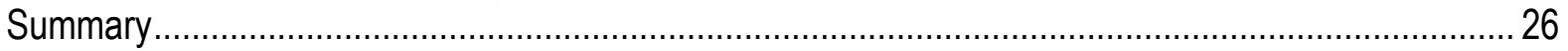

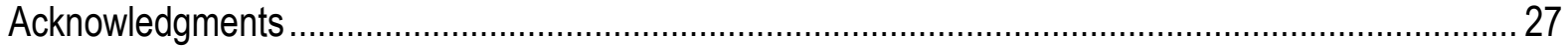

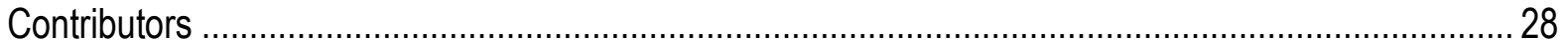

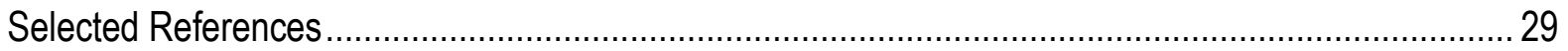

\section{Figures}

1. Map showing probabilistic seismic hazards for the central and eastern United States with locations of existing Advanced National Seismic System stations and nuclear powerplant

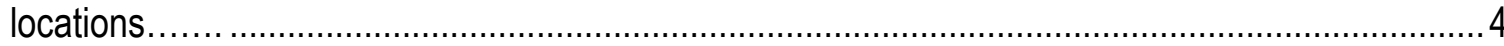

2. Map showing seismic broadband and strong-motion stations in the eastern United States slated to be upgraded under the American Recovery and Reinvestment Act ...........6

3. Map illustrating existing seismic stations in the central United States including stations to be upgraded under the American Recovery and Reinvestment Act

4. Map of existing seismic stations in the central and eastern United States and planned upgrades under the American Recovery and Reinvestment Act .....

5. Summary map of relative earthquake locations near Oklahoma City, Oklahoma, January and February 2010, using existing stations, the Transportable Array, and temporary NetQuakes strong-motion recorders.

6. Seismograms and regional moment tensor results from the February 2010 M 3.2 Oklahoma earthquakes.

7. Map showing location of the February 2010 northern Illinois earthquake, nuclear plants, and seismic stations of the Advanced National Seismic System

8. Map showing macroseismic intensities near Elgin, Illinois, from the February 2010 earthquake, from web-based entries

9. Example ShakeCast output showing seismic intensities from the February 2010 earthquake at near-field nuclear plants, Illinois. 
10. Overview of the ShakeCast system for quantifying and displaying earthquake ground-shaking information, from the user's perspective

11. Example of ShakeCast information delivery from the M 7.8 San Andreas scenario earthquake ....24

\section{Table}

1. Table showing generic description of strong-motion system options

\section{Abbreviations}

$\begin{array}{ll}\text { ANSS } & \text { Advanced National Seismic System } \\ \text { ARRA } & \text { American Recovery and Reinvestment Act } \\ \text { CERI } & \text { Center for Earthquake Research and Information, University of Memphis } \\ \text { CEUS } & \text { Central and eastern United States } \\ \text { ENS } & \text { Earthquake Notification System (ANSS product) } \\ \text { FEMA } & \text { Federal Emergency Management Agency } \\ \text { IRIS } & \text { Incorporated Research Institutions for Seismology } \\ \text { NEHRP } & \text { National Earthquake Hazards Reduction Program, U.S. Geological Survey } \\ \text { NEIC } & \text { National Earthquake Information Center, U.S. Geological Survey } \\ \text { NSHM } & \text { National Seismic Hazard Maps, U.S. Geological Survey } \\ \text { RSNs } & \text { Regional Seismic Networks } \\ \text { TA } & \text { Transportable Array of EarthScope (National Science Foundation and IRIS) } \\ \text { USGS } & \text { U.S. Geological Survey } \\ \text { USNRC } & \text { U.S. Nuclear Regulatory Commission } \\ \text { CISN-Display } & \text { California Integrated Seismic Network-Display (ANSS product) } \\ \end{array}$




\title{
Improved Earthquake Monitoring in the Central and Eastern United States in Support of Seismic Assessments for Critical Facilities
}

\author{
By William S. Leith, Harley M. Benz, and Robert B. Herrmann
}

\section{Introduction}

This report was developed in response to a request by the U.S. Nuclear Regulatory Commission (USNRC) for evaluation of seismic monitoring capabilities in the central and eastern United States (abbreviated in this report as CEUS) with an emphasis on meeting current and future needs of the USNRC. This "Phase II" report focuses on specific improvements to earthquake monitoring in the CEUS likely to further the USNRC's goals for improved understanding of seismic hazards within this region.

This report is not an assessment of the seismic safety of nuclear powerplants (NPPs) in the CEUS. The USNRC is responsible for assessing the seismic safety of individual NPP's, but based on specific seismic and engineering information not considered in this report.

To accomplish this evaluation task, the report provides an update on the current state of earthquake monitoring in the CEUS, a description of seismic upgrades in the CEUS supported by the U.S. Geological Survey through the American Recovery and Reinvestment Act (ARRA) of 2009, and proposals for deployment of new instrumentation. The report also proposes the adoption of earthquake notification and emergency response tools using Advanced National Seismic System (ANSS) earthquake information and products that show the distribution of ground shaking from significant earthquakes. The assessment and findings in this report, developed herein at the request of the NRC, would also benefit other federal and state entities with responsibility for critical infrastructure in the region.

Enhancements in earthquake monitoring in the CEUS which could result in an improved understanding of seismic hazards and improved situational awareness after earthquakes are as follows:

- 38 new Advanced National Seismic System strong-motion stations in active CEUS earthquake source zones to improve seismic monitoring infrastructure for response, assessment and mitigation;

- 62 new strong-motion stations near nuclear powerplants to record near-nuclear-plant ground shaking;

- expanded databases of strong ground-motion data and Green's Function data for earthquake source characterization, attenuation, and propagation across the CEUS; and

- improved ShakeMap and ShakeCast tools at the USNRC and other state and Federal users for rapid response and assessment activities.

Numerous strategies exist for improved seismic monitoring throughout the region, each with associated trade-offs and costs. For example, comprehensive seismic monitoring throughout the region comparable to that found in California (which is broadly monitored at magnitude threshold 
of M 1.8-2.0) would require hundreds of new stations, capitalization costs in the tens of millions of dollars, and associated long-term operation and maintenance costs in the millions of dollars. Over the long term, such a network would guarantee seismic catalog completeness to lower magnitudes (likely less than M 2), accurate earthquake locations (in the range $\pm 1-2$ kilometers, $\mathrm{km}$ ), improved understanding of seismotectonics, and better models of near-source and regional attenuation.

Recognizing that dense, permanent deployments of new stations throughout the CEUS are not likely, a pragmatic approach utilizes augmentation of existing deployments to ensure better characterization of the seismotectonics of notable seismic source zones in the CEUS. Such augmentation would improve quantification of near-source attenuation in regions where larger earthquakes are expected, as well as support systematic collection of data and observations from existing permanent and temporary networks, ultimately to improve estimates of earthquake source parameters, attenuation, and propagation. While this approach costs less to implement and operate than does the dense-deployment approach, it requires careful modeling and calibration efforts to improve determination of earthquake locations for larger events (those typically greater than M 2.53.0) and limits catalog completeness to a higher threshold (that is, M 2.5 or larger). Augmentation, however, will provide limited near-source data for the rare event that is outside of the more densely monitored source zones.

Knowing that it operates limited seismic monitoring assets in the CEUS, the U.S. Geological Survey has begun development of modeling procedures and processing algorithms to leverage unique capabilities of the Transportable Array and the upgraded Advanced National Seismic System stations to better calibrate source and path effects. The EarthScope Transportable Array (funded by the National Science Foundation and implemented by the IRIS Consortium) is an approximately 400-station network that is rolling across the country collecting continuous seismic data for approximately 18 months at each site. When completed, the Transportable Array will provide temporary, but uniform, coverage of the continental United States with an interstation spacing of about $70 \mathrm{~km}$.

Many of the determinations in this report are based on the assumption that active research and development within the USGS National Earthquake Hazards Reduction Program and leveraged results and products from the Transportable Array together provide new capabilities using existing and augmented systems to address hazards of interest to both the U.S. Geological Survey and to the U.S. Nuclear Regulatory Commission, as well as to other state and Federal agencies.

\section{Augmentations to Regional Seismic Networks and the Advanced National Seismic System}

\section{Coordinated Station Upgrades and Infrastructure Improvements for Seismic Monitoring}

Both the U.S. Geological Survey (USGS) and the U.S. Nuclear Regulatory Commission (USNRC) have an interest in improved seismic monitoring across the United States, particularly for hazard mitigation and response. The USGS and USNRC perform complementary missions of addressing earthquake hazards that lead to efficient and effective damage- and loss-mitigation policies. The American Recovery and Reinvestment (ARRA) Act of 2009 provided a rare opportunity to coordinate upgrades of seismographic stations to achieve objectives of better acquisition and processing of seismic data of engineering interest, better constraints on earthquake source parameters (location, magnitude, and style of faulting) used in assessment and mitigation activities, and better dissemination of earthquake information to assist in post-earthquake response and recovery activities. 
Given the areal distribution of seismic source zones and limited deployment of stations within active earthquake source zones, seismic monitoring capabilities vary considerably across the CEUS. Identification and characterization of seismically active structures are important input for the USGS National Seismic Hazard Maps (NSHM) and also are a requirement for site-specific seismic-hazard analyses for most critical structures, including nuclear powerplants. To better characterize seismic source zones, accurate locations (within 1-2 km or less) for all earthquakes down to the smallest practical magnitude is desired, since spatial seismicity trends may be an important indicator of the location of seismically active geologic structures. Overall, regional seismic networks (RSNs) in the CEUS do an adequate job of documenting earthquake source parameters across the region as a whole and a good job in selected source regions (for example, the New Madrid seismic zone), which reflects traditional USGS hazard-mitigation priorities. For development of the NSHMs, earthquake-data completeness for the CEUS down to M 3.0-3.5 is needed with an epicentral accuracy of about 3-5 km. On the other hand, however, site-specific seismic hazard studies at a critical facility, such as a nuclear powerplant (NPP), might require a complete database of earthquakes within $200 \mathrm{~km}$ of the site down to M 2.0 or lower to support the most robust estimates possible of local seismicity rates and to provide the largest possible dataset for identifying potentially active structures. Through the ARRA project, the USGS has tried to balance the need to target upgrades in areas of highest seismic hazard (such as eastern Tennessee, upstate New York, and the New Madrid zone) while also improving areal monitoring to assist USNRC in its broader earthquake assessment and mitigation activities.

\section{Improved Near-Source Monitoring through Coordinated Upgrades of Existing Seismographic Stations and Infrastructure through the American Recovery and Reinvestment Act}

On the basis of geological and geodetic constraints, such as seismicity, probabilistic seismic hazard maps (fig. 1) highlight those areas of the CEUS that have a high likelihood of experiencing significant ground motions during the nominal 20-year lifetime of any seismic instrumentation. Strategically deployed seismographic stations in critical areas provide essential data that can be used to better characterize the seismotectonics of active CEUS source zones through better constraints on earthquake source properties (for example, depth, moment-magnitude, or mechanism) critical in improving earthquake ground-motion scaling relations and attenuation models.

A plot of existing seismic stations and NPPs on the probabilistic NSHM of the United States (fig. 1) provides a framework for understanding the present state of monitoring. It also provides a basis for identifying gaps in monitoring capabilities. The distribution of seismic stations in the CEUS shows a two-tiered approach to monitoring (fig. 1). Throughout the United States there is a uniform deployment of widely spaced broadband/strong-motion stations that makes up the ANSS backbone network. Each of these stations is capable of recording at 200 samples per second and up to $\pm 2 \mathrm{~g}$ of acceleration. The backbone network guarantees uniform monitoring of the continental United States to a level of about $\mathrm{M}$ 3 with location errors within 5-10 km and magnitude uncertainties of \pm 0.2 magnitude units. This network complements denser networks of stations in selected seismic source zones (for example, eastern Tennessee, upstate New York, and the New Madrid Fault Zone) with lower detection thresholds, typically below M 2. These dense networks of stations provide detailed information on earthquake source characteristics for seismic source zones of interest to the USGS National Earthquake Hazards Reduction Program and State monitoring programs (for example, that of the State of Tennessee). Although the USGS and its monitoring partners try to place seismograph stations in most of the expected source zones, many of these source zones are inadequately monitored in terms of catalog completeness to low magnitudes, earthquake location accuracy, and on-scale ground motion recordings for earthquakes of engineering interest. Many such high-gain, short-period stations cannot stay on-scale for events larger than approximately M 3.0 at distances less than 100-150 km. 


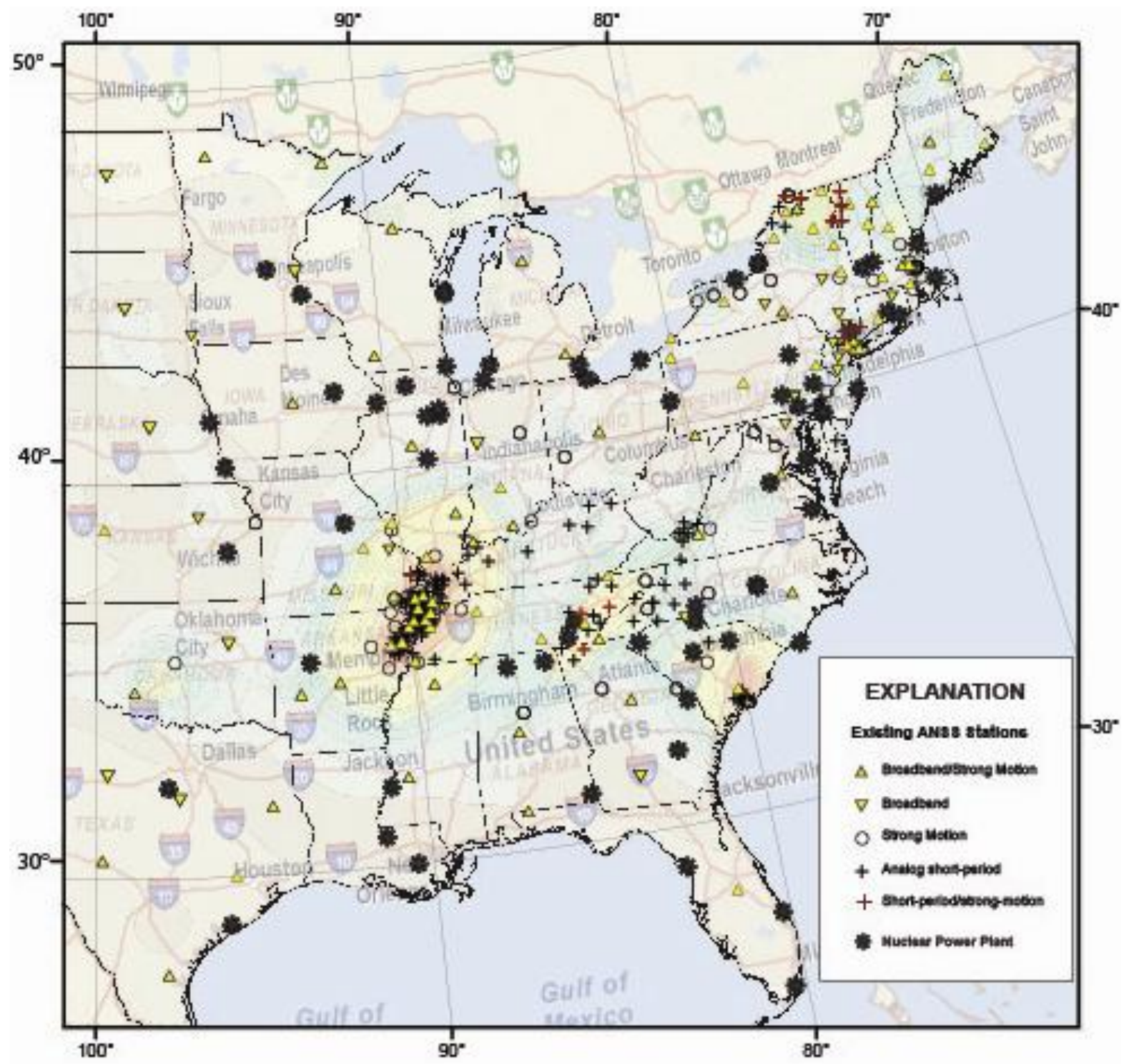

Figure 1. Map showing probabilistic seismic hazards ( $0.1 \mathrm{~g}$ in 50 years) for the central and eastern United States with locations of existing Advanced National Seismic System stations and nuclear powerplant locations.

\section{Seismic Hazard in the Northeastern United States}

In the northeastern United States, the seismic hazard is dominated by seismic activity associated with the St. Lawrence rift zone, which has produced some of the largest eastern North American earthquakes (for example, eastern Canada earthquakes of note include the 1925 M 6.2 Charlevoix, 1988 M 5.9 Saguenay, and 1944 M 5.6 Cornwall, Canada, and Massena, New York, earthquakes). Seismic activity in or near the St. Lawrence rift zone is seen as the highest hazard 
region in upstate New York and northern Maine. Historically, there have been significant earthquakes elsewhere in the northeastern United States, with notable events in western New York, Massachusetts, New Jersey, Pennsylvania, Ohio, and Maine. The two largest earthquakes reported in the northeast were the M 6+ earthquake of 1638 (central New Hampshire) and the 1755 earthquake offshore Massachusetts, near Cape Ann. In the $20^{\text {th }}$ century, there have been a number of earthquakes in the M 5 range in upstate New York, Maine, and Pennsylvania.

Because of the lack of well-defined seismic source zones in the northeastern United States, a major goal of seismic monitoring is to capture on-scale strong ground-motion records in near-source regions and urban environments that are at risk to rare but significant earthquakes. Consequently, seismographic stations are deployed in and around upstate New York and near the metropolitan areas of New York and Boston, with more widely spaced stations in Pennsylvania, New York, and New England. Earthquake source zones that remain sparsely monitored include northern-most Maine, northeastern Ohio, western Pennsylvania, and western and upstate New York.

\section{Seismic Hazard in the Southeastern United States}

The southeastern United States contains at least two seismic zones of elevated hazard: the Charleston, South Carolina, zone and the eastern Tennessee zone. The Charleston Seismic Zone (CSZ), sometimes also called the Middleton Place-Summerville Seismic Zone, is the source of the largest historically documented earthquake in the CEUS after the New Madrid sequence of 1811-1812: the M 7+ earthquake near Charleston in 1886. The historic record contains many other large felt earthquakes and widespread paleoseismic and paleoliquifaction data that suggest prehistoric levels of shaking sufficient to produce nonlinear site responses about every 500 years over the last 6,000 years. Elevated levels of hazard with a 10 percent probability of shaking in the 0.02-0.04 g range span nearly the entire state of South Carolina, for example. Current monitoring in the CSZ (fig. 2) consists of three broadband and three digital short-period stations together with four free-field strong-motion stations operating in near-real-time in the Charleston/Summerville metropolitan area.

The East Tennessee Seismic Zone (ETSZ) is the second most active zone in the CEUS and covers a 100- by 300-mile swath across northeastern Alabama, northwestern Georgia, eastern Tennessee, western North Carolina, southeastern Kentucky, and southwestern Virginia (fig. 1). The largest instrumentally recorded earthquakes in the region were the April 29, 2003, M 4.6 near Fort Payne, Alabama, and the November 30, 1973, M 4.6 earthquake south of Knoxville, Tennessee. Paleoseismic evidence for large historical earthquakes has not been developed as yet. Seismogenic depths within the ETSZ typically are 5-22 km, with most events occurring on steeply dipping faults beneath a Paleozoic décollement, a large-scale shallow-angle fault or shear zone. Focal mechanisms are remarkably consistent along the entire length of the zone and suggest strike-slip motion on an organized set of basement faults. Current monitoring in the ETSZ is accomplished with a network of 23 three-component analog short-period (SP) stations (at about 25-km interstation spacing), three three-component broadband stations, and three three-component free-field strong-motion stations (fig. 2). While relatively dense in terms of total instrumentation, the analog SP stations will clip for earthquakes larger than about M 2-2.5 within the ETSZ. 


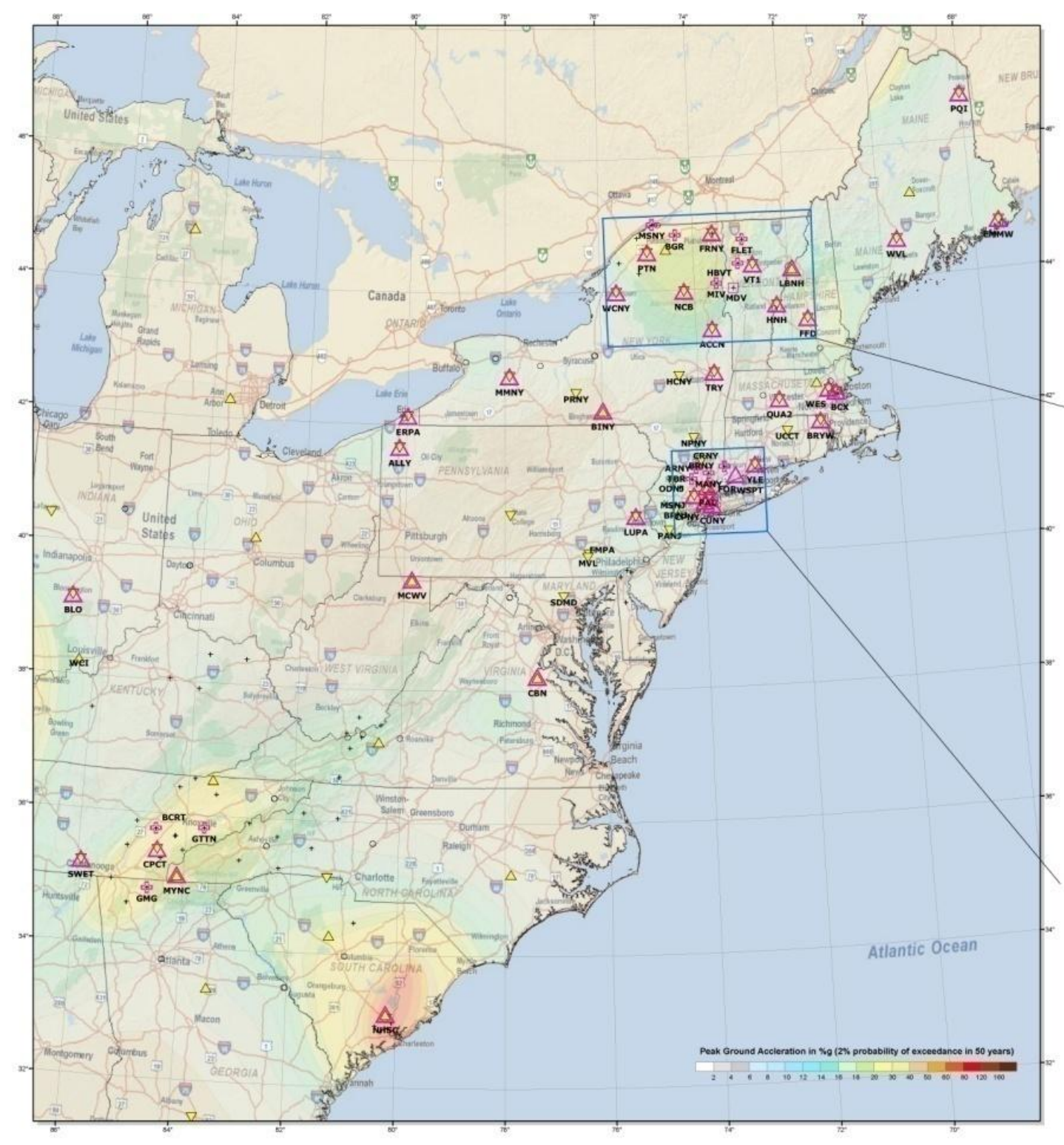

ARRA Station Upgrades

$\triangle$ Broadband/Strong Motion

Strong Motion

Short Period

\section{Existing Stations}

$\Delta$ Backbone Broadband/Strong Motion

Backbone Broadband

$\nabla$ Broadband

of Strong Motion

+ Short Period

Background: Peak ground acceleration having a $2 \%$ probability of exceedance in 50 years.
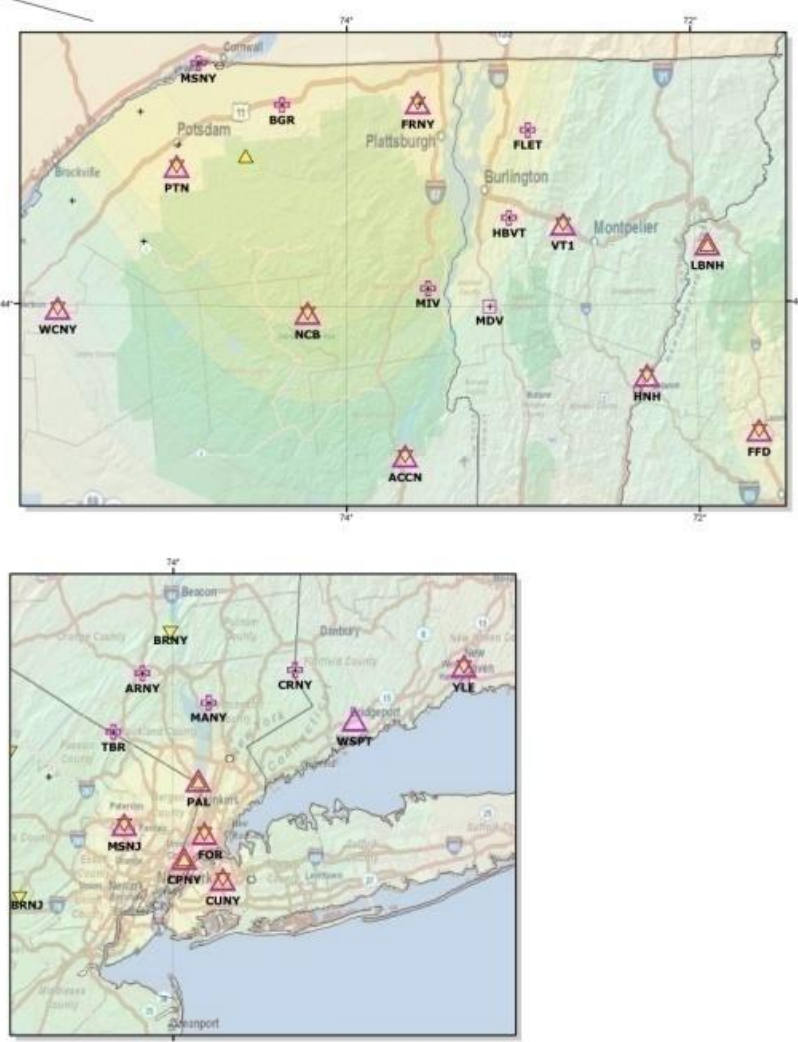

Figure 2. Map showing seismic broadband and strong-motion stations (outlined with magenta symbols) in the eastern United States slated to be upgraded under the American Recovery and Reinvestment Act (ARRA). The ARRA upgrades include both broadband plus strong-motion sites (triangles) and short-period plus strong-motion sites (plus signs). 


\section{Seismic Hazard in the Central United States}

The seismic hazard in the central United States (fig. 1) is spatially distributed, with major seismic source zones of elevated hazard in and around the New Madrid Seismic Zone in southeastern Missouri and adjacent parts of Illinois, Kentucky, Tennessee, and Arkansas, and in the Wabash Valley Seismic Zone in Indiana and Illinois. The New Madrid and Wabash Valley Seismic Zones are roughly contiguous and stand out on probabilistic seismic hazard maps as a region of high likelihood for exceeding $0.1 \mathrm{~g}$ in a 50-year-period (fig. 1).

The New Madrid zone produced three powerful earthquakes between M 7.0-8.0 in 1811-12, as well as previous sequences of large earthquakes in about 1450 and 900 A.D., documented by paleoliquefaction evidence. The narrow, approximately $500 \mathrm{~km}$-long zone between Marked Tree, Arkansas, and Mt. Carmel, Illinois, has seen about $25 \mathrm{M}>4$ earthquakes in the last 50 years. Although the probability of observing $0.1 \mathrm{~g}$ at any given location along this zone is only about 2 percent annually, the aggregate likelihood of observing $0.1 \mathrm{~g}$ somewhere in this zone is much higher.

While the current distribution of upgraded broadband seismographs and accelerographs in the most active portion of the NMSZ yields station spacing of about $25 \mathrm{~km}$ (fig. 3), the larger area likely to experience strong shaking has average station separation of about $50-100 \mathrm{~km}$. That network is too sparse to capture on-scale the necessary near-source ground-motions, to constrain closely hypocenters, or to resolve amplitude-versus-distance scaling issues. This report will address the need for instruments capable of on-scale recording within $50 \mathrm{~km}$ of expected earthquake sources.

\section{Recent Improvements to the Advanced National Seismic System and Regional Seismic Networks}

The American Recovery and Reinvestment Act (ARRA) funding has been used by the USGS to upgrade the ANSS backbone network and regional seismic networks (RSNs) to ensure region-wide monitoring at high fidelity. In addition, the USGS provided ARRA money to the University of Memphis, Saint Louis University, Weston Observatory of Boston College, and the Lamont-Doherty Earth Observatory of Columbia University to upgrade their regional broadband stations to newer and quieter broadband sensors and to add three channels of strong-motion data to each station. Some short-period stations in higher-hazard source zones (for example, upstate New York and the ETSZ) also are being upgraded to include strong-motion sensors (figs. 2 and 3).

Through the ARRA, the USGS is making a major investment in seismic monitoring in the CEUS. A total of 80 existing seismic stations in the region will be upgraded to modern ANSS standards of high-dynamic-range recording of low-noise accelerometers and either low-noise broadband or short-period sensors. In addition, the USGS is upgrading the regional network operation centers to ensure comprehensive cataloging of ground-motion data and earthquake source parameters using well-defined standards of data exchange and processing and descriptions of instrument response. When completed by the end of calendar year 2011, such upgrades will improve significantly the ability of ANSS to record ground-motion data for M 3 and larger earthquakes of engineering interest within some of the key CEUS active source zones. 


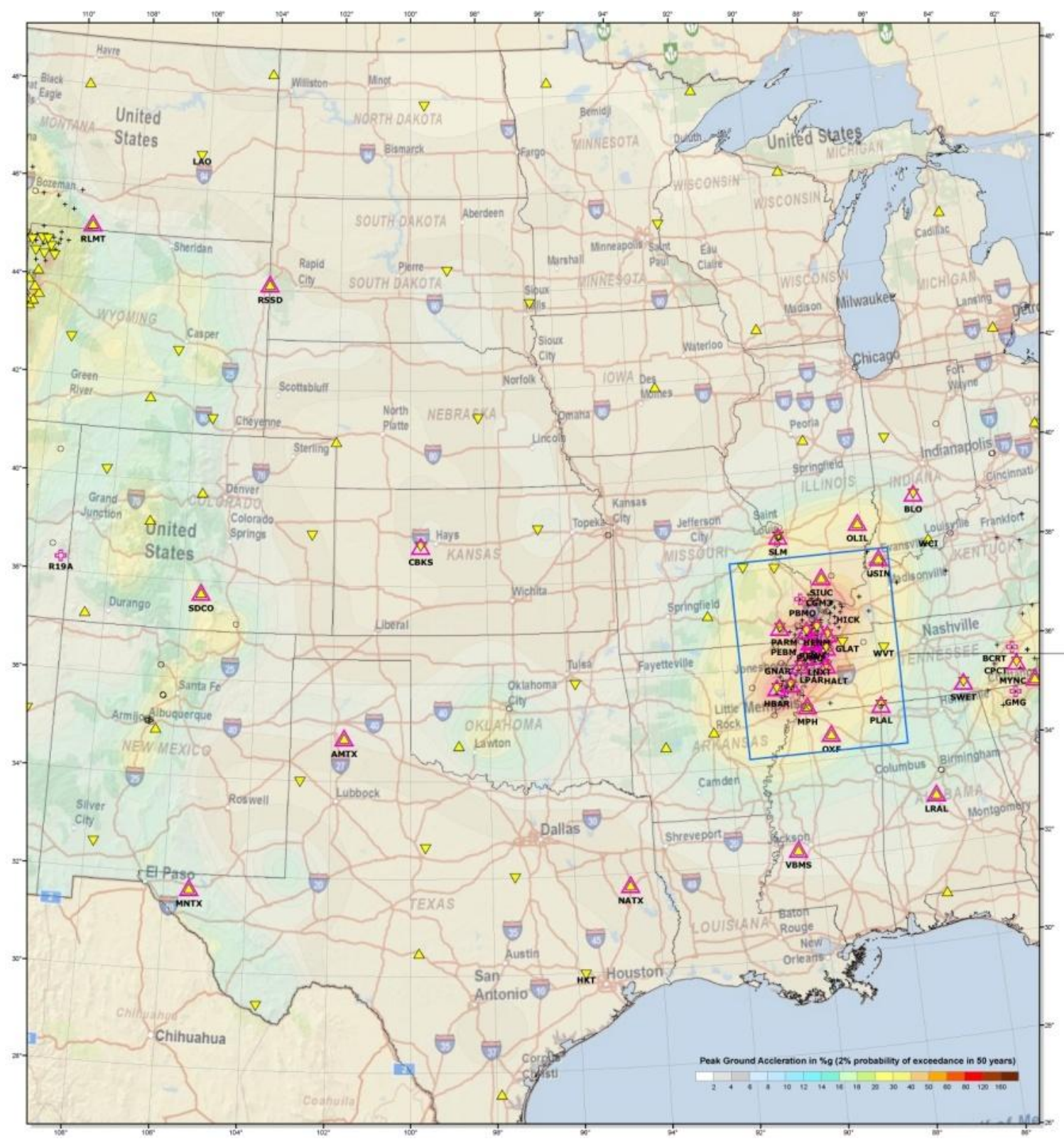

ARRA Station Upgrades

$\triangle$ Broadband/Strong Motion

O Strong Motion

- Short Period/Strong Motion

\section{Existing Stations}

A Backbone Broadband/Strong Motion

$\checkmark$ Backbone Broadband

Broadband/Strong Motion

$\nabla$ Broadband

+ Short Period

Background: Peak ground acceleration having a $2 \%$ probability of exceedance in 50 years.

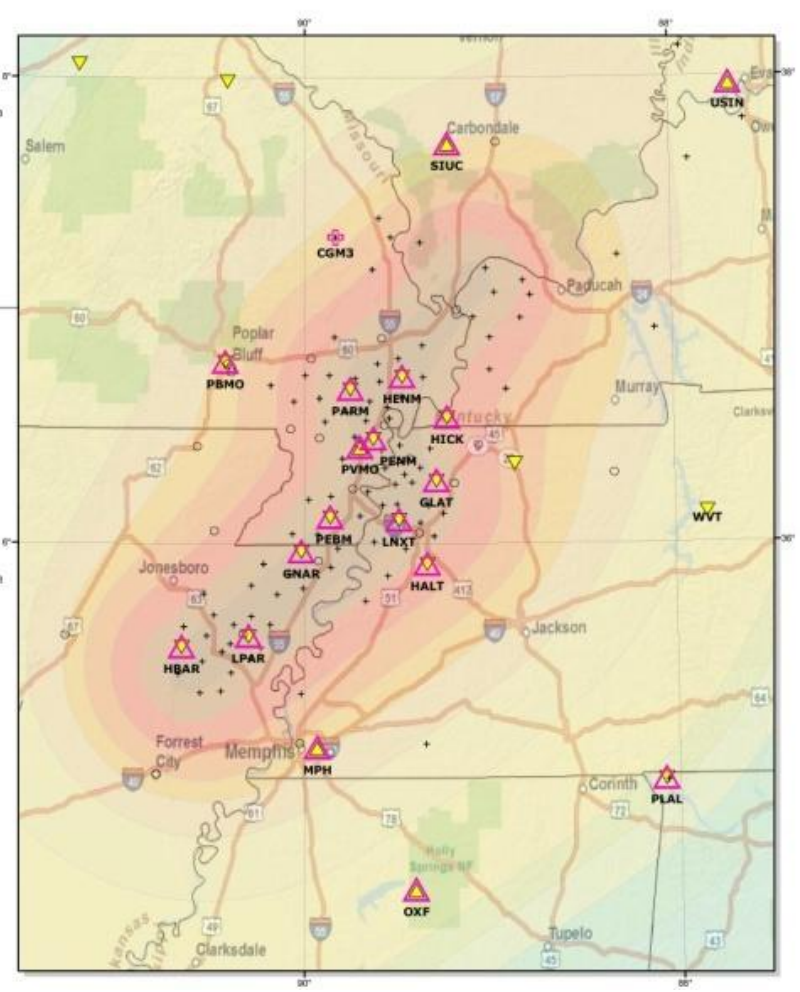

Figure 3. Map of existing seismic stations in the central United States and planned station upgrades under American Recovery and Reinvestment Act. Stations outlined with pink symbols identify stations slated for upgrades. 
The National Science Foundation (NSF)-sponsored EarthScope project also plays a significant role in improving seismic monitoring of the CEUS. As part of EarthScope, IRIS has deployed a 400-station temporary array of broadband stations called the Transportable Array (TA) that is rolling across the United States. (The rearmost station is moved to the lead position as the array "rolls" from west to east.) Each station is operated for 18-24 months before being moved to a new location along the traverse. Interstation spacing for this moving network is approximately $70 \mathrm{~km}$. By providing uniform sampling across the continental United States, the TA network will enable the USGS and USNRC to "calibrate" crustal structure, which has implications for improved earthquake-location determinations and synthetic seismogram calculations used in moment-tensor descriptions of earthquakes. In addition, as the TA rolls across the country, the USGS and USNRC have an opportunity to evaluate individual stations for adoption into existing network operations in order to add them as permanent stations and improve overall network capabilities.

Suggested research and development activities involving coordination of USGS, USNRC and university scientists include:

- Work with the Department of Energy (DOE) national laboratories and through the National Earthquake Hazards Research Program (NEHRP) external grants program to use the TA data and ground-truth events to improve estimates of velocity structure needed in routine location and waveform-modeling procedures.

- Collect accurate interstation Green's Function data that can be used in a variety of standard and novel modeling procedures better to determine earthquake epicenters, depths, and moment-tensor parameters without the need for costly expansion of stations outside the expected areas of activity.

- Supplement United States ground-motion datasets with strong-motion data along the United States-Canada border from Canadian stations integrated into ANSS operations.

- Establish an ad-hoc advisory committee of USGS and USNRC personnel to prioritize seismic-monitoring research and development efforts in the CEUS using existing funding structures such as specific elements of the NEHRP external grants program.

- Develop with the RSNs evaluation criteria and procedures to identify key TA stations that could be adopted as part of a long-term monitoring strategy.

Activities that are underway or are being considered to address some of these research and development efforts include:

- Department of Energy (DOE) national laboratories are developing improved velocity models of the United States for explosion monitoring and verification as part of the United States-supported Comprehensive Test Ban Treaty augmentation. The USGS National Earthquake Information Center has provided Lawrence Livermore National Laboratory well-documented ground-truth events for the continental United States, which are necessary to calibrate such continental-scale velocity models. It is expected that such calibration efforts will reduce location biases/errors by at least a factor of 2 .

- The USGS is supporting a two-year Mendenhall postdoctoral fellowship to investigate new approaches for use of interstation Green's Function data derived from ambient-noise data under a primary focus of addressing issues related to three-dimensional basin and regional effects on seismic ground motions. The USGS also is investigating new location procedures using interstation Green's Function data derived from both the TA network and existing ANSS stations. 
- The USGS Geologic Hazards Science Center systematically is storing all such interstation Green's Functions derived from USGS studies for easy access in future seismic ground-motion studies, computation of improved crust and upper-mantle velocity models, and improved estimations of source parameters.

- The USGS National Earthquake Information Center (NEIC) presently is acquiring data from Geological Survey of Canada (GSC) strong-motion stations from Haiti in real-time.

- The USGS has developed procedures to automatically extract ground-motion parameters of engineering interest from both broadband and strong-motion time-series data for use by the USGS National Strong Motion Project.

- The State of Arkansas is adopting six TA stations with USGS funding. Consequently, the University of Arkansas/Little Rock, CERI (the University of Memphis Center for Earthquake Research and Information), and the USGS are working together to ensure that adopted stations meet minimum performance standards and address regional monitoring and hazards issues. The effort could be considered a pilot for developing a process for strategic adoption of other TA stations in the CEUS.

These efforts leverage the ARRA upgrades to existing networks, recognize the importance of EarthScope Transportable Array deployment to improve models and modeling procedures, and use existing USGS research activities and staff to facilitate the research and development needed to provide new and more accurate monitoring products.

\section{Augmentation of Seismic Networks to Support Critical Facilities Requirements}

Detailed hazard assessments at nuclear powerplants in the CEUS are based on models of earthquake ground motions for moderate and large earthquakes largely derived from recordings of small earthquakes $(\mathrm{M}<5)$ in the CEUS. The primary sources of data for such assessments come from USGS-supported or -operated seismic networks. The uncertainty in ground-motion prediction models is one of the largest sources of total uncertainty in probabilistic seismic hazard results. In order to reduce this component of uncertainty in hazard assessments, it is appropriate to consider potential improvements in the groundmotion and source-parameter database of small and moderate earthquakes in the CEUS through strategic deployment of stations in selected seismic source regions and in the vicinity of critical facilities.

Because the USGS and its regional partners operate broad-based seismic monitoring networks in the CEUS, adding new stations to existing monitoring systems is relatively easy and cost-effective and carries a high probability of success. The USGS National Earthquake Information Center and RSNs in the CEUS easily can handle new stations and integrate resulting data into existing processing algorithms to produce timely and accurate earthquake information products tailored to meet specific agency mission requirements. Additionally, the Advanced National Seismic System (ANSS) has established standards for all aspects of its monitoring efforts (including, for example, instrumentation standards, station metadata standards, and data-exchange protocols and formats). Considering all of these factors, it is cost-effective for the USGS or other funding partners to collaborate on improved seismic monitoring in the CEUS through upgrades of existing sensor systems or installation of new stations where recognized deficiencies in coverage appear. Ultimately, targeted upgrades integrated into existing processing systems improve general and task-specific performance, which in turn reduces uncertainty in hazard estimates for low-probability events and provides more confidence in seismic design. 
To improve the strong-motion database of earthquakes in the CEUS, it is important that the number of operating strong-motion stations be increased throughout the region to ensure capture of infrequent earthquakes of engineering interest. Figure 4 indicates locations of existing seismic stations operated by the USGS and RSNs, along with suggested upgrades and additions of new stations. In order to address the need to compute accurately earthquake source parameters and to understand site response and propagation effects at or near NPPs or other critical facilities, the USGS suggests upgrading or installing an additional 100 stations. Some of those new or upgraded stations are targeted at under-instrumented earthquake source regions; others are sited near critical facilities. Both sets of instrumentation will improve estimates of source parameters, increase understanding of propagation and attenuation relationships across the region, and enhance understanding of site-specific assessments at each of the critical facilities.

In many parts of the CEUS, especially the northeastern and southeastern United States, the density of seismic stations is not sufficient to achieve optimum monitoring for site-specific seismic hazard studies. To provide accurate hypocentral determinations for earthquakes down to M 2.0, for example, four to six seismic stations at hypocentral distances less than 50-150 km surrounding expected earthquakes are necessary. In addition, bettercalibrated velocity models for the CEUS should be developed. Consequently, the USGS and RSNs have identified 38 new or potential upgraded strong-motion sites (blue squares in fig. 4) in seismic source zones that are not adequately monitored at present (meaning either no stations within about $50 \mathrm{~km}$, or existing stations which cannot remain on-scale for anticipated seismicity occurring within $50 \mathrm{~km}$ ). The majority of these stations either augment existing networks (for example, in the New Madrid Seismic Zone or the Eastern Tennessee Seismic Zone) or provide new monitoring capabilities where none existed before (such as in central Oklahoma or in the Rio Grande Rift of north-central New Mexico). In some areas, such as western Colorado, existing short-period/broad-band networks currently are used for basic monitoring, but additional or upgraded stations are needed to ensure high-quality ground-motion recording within $50 \mathrm{~km}$ of a potential moderate to large earthquake.

In addition to deployment of 38 strong-motion stations to improve the performance of seismic monitoring installations across the region, the USGS suggests deployment of 62 new real-time strong-motion stations near or at critical facilities sites in the CEUS. Many of the proposed stations fall outside an ANSS deployment strategy (that is, upgrading and increasing the numbers of stations within CEUS active seismic-source zones of interest to the USGS Earthquake Hazards Program). In some cases, critical facilities are within or near active source zones (for example, the Eastern Tennessee Seismic Zone and the Charleston Seismic Zone), and any upgrades near those facilities would perform a dual purpose of better characterization of earthquake source parameters and near-facilities site effects. Installation of new strong-motion stations at or near other critical facilities mainly would be used for evaluation of site response and regional propagation issues and additionally would be used in emergency-response applications like ShakeMap and ShakeCast. Note that both ShakeMap and ShakeCast are USGS products that are used regionally and by specific responding agencies, such as USNRC and FEMA. Combined, the addition of 100 new or upgraded stations would allow ANSS to compute earthquake source parameters more accurately for response and mitigation activities and would ensure a high likelihood of capturing on-scale ground motions within $50 \mathrm{~km}$ of expected moderate to large earthquakes. The additional stations also would address regional source and propagation issues of interest to USNRC. 


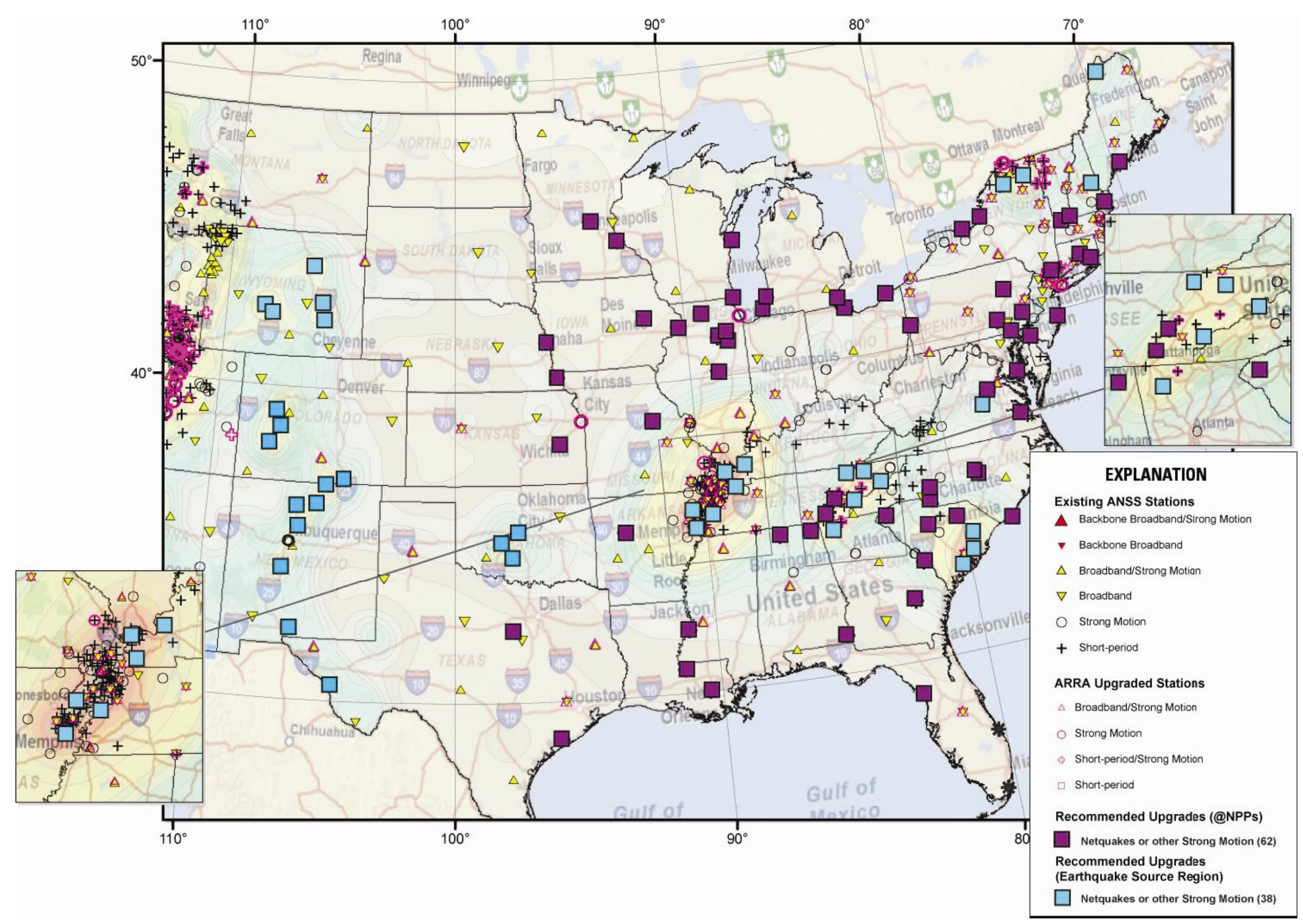

Figure 4. Map showing existing seismic stations in the central United States and planned station upgrades under American Recovery and Reinvestment Act (ARRA) activities (outlined in pink). Proposed augmentations are shown as blue squares (with seismic source zones) and purple squares (at or near nuclear powerplants). 


\section{Potential Strong-Motion Recording Options}

Through development of technical standards, the USGS has pursued deployment of "Class A" and "Class B" strong-motion systems for complementary uses in the regional networks. Class A systems are characterized by high-fidelity digitizers (nominal 19-22 bits of resolution) and lownoise accelerometers (about $-140 \mathrm{~dB}$ self-noise at $1 \mathrm{~Hz}$ ), while Class B systems are characterized by digitizers with lower nominal resolution of about 18 bits and accelerometer self-noise of about $120 \mathrm{~dB}$ at $1 \mathrm{~Hz}$. The difference between these two systems translates into about a factor of three in life-cycle cost, with Class A systems naturally costing more. Experience has taught that both systems have appropriate roles in long-term network monitoring within the United States, with Class A systems in quiet and more widely spaced deployments but Class B stations in noisy and/or denser deployments. Presently, NetQuakes systems (a Class B instrument manufactured by GeoSIG, Ltd., Switzerland) primarily are deployed in large numbers in culturally noisy, urban environments to improve the density of strong-motion recordings that go into urban ShakeMap outputs and to address issues of site response and resonance in the built-up environment. Class A systems primarily are deployed within RSNs in near-source regions to help with earthquake earlywarning algorithms (as in California) and routine monitoring of zones of active seismicity. Because of the relatively high life-cycle costs of Class A systems, fewer are being deployed, and networks employing a complementary mix of the two station classes are growing. Table 1 provides some generic features of possible strong-motion systems that could be part of upgrades to CEUS regional seismic networks.

Table 1. Generic description of strong-motion system options. Class A systems typically cost about $\$ 15,000-$ 20,000 to purchase and install, while Class B systems typically cost about $\$ 10,000$ to purchase and install. Operating costs range from about $\$ 2,000-5,000$ per year, depending on locality and telemetry options.

\begin{tabular}{|c|c|c|c|c|}
\hline $\begin{array}{l}\text { System } \\
\text { Class }\end{array}$ & $\begin{array}{c}\text { Digitizer } \\
\text { Resolution }\end{array}$ & $\begin{array}{l}\text { Sensor Self-Noise } \\
\text { and Capabilities }\end{array}$ & $\begin{array}{c}\text { Typical } \\
\text { Applications }\end{array}$ & $\begin{array}{c}\text { Available } \\
\text { Configurations }\end{array}$ \\
\hline $\boldsymbol{A}$ & $\begin{array}{c}\text { High } \\
(19-22 \text { bits })\end{array}$ & $\begin{array}{l}\text { Low }(-140 \mathrm{~dB}) \text {; } \\
\text { high structural modes, } \\
\text { Green's functions, } \\
\text { source studies, and } \\
\text { similarly resolution- } \\
\text { sensitive tasks }\end{array}$ & $\begin{array}{l}\text { Early warning; } \\
\text { ShakeMap; near- } \\
\text { source monitoring; } \\
\text { aftershock capture; } \\
\text { reference, free-field, } \\
\text { and structural arrays }\end{array}$ & $\begin{array}{c}\text { Multiple sensor types; } \\
\text { continuous real-time } \\
\text { telemetry; maintained } \\
\text { by professional field } \\
\text { technicians }\end{array}$ \\
\hline $\boldsymbol{B}$ & $\begin{array}{l}\text { Medium } \\
(16-18 \text { bits })\end{array}$ & $\begin{array}{l}\text { Medium }(-120 \mathrm{~dB}) ; \\
\text { enough precision to } \\
\text { compute engineering } \\
\text { and emergency-response } \\
\text { metrics (PGA, PGV, } S_{a} \text {, } \\
\text { etc.) to accuracies one } \\
\text { order better than typical } \\
\text { instrument calibrations }\end{array}$ & $\begin{array}{l}\text { Reference, free- } \\
\text { field, and urban } \\
\text { sites; array infill; } \\
\text { ShakeMap; aftershock } \\
\text { capture; spatial } \\
\text { covariance and } \\
\text { uncertainty studies }\end{array}$ & $\begin{array}{l}\text { Accelerometers only; } \\
\text { triggered and polled; } \\
\text { designed for routine } \\
\text { maintenance by less } \\
\text { experienced hosts } \\
\text { without loss of } \\
\text { confidence }\end{array}$ \\
\hline
\end{tabular}




\section{Justification for Enhanced Monitoring-Case Studies in Oklahoma and Illinois}

\section{Oklahoma Case Study: 2009-2010 Oklahoma Earthquake Swarm Northeast of Oklahoma City}

Of about 50 measurable earthquakes each year in Oklahoma, only a few have shaking strong enough to be felt. In 2009, however, there were 43 felt earthquakes throughout the state, with 34 occurring in Oklahoma County or in Lincoln County near Norman, Oklahoma. Following an M 3.8 earthquake on January 15, 2010, the largest to date in the sequence, the USGS assisted the Oklahoma Geological Survey in deploying six USGS NetQuakes strong-motion systems in the vicinity of the felt seismicity (fig. 5).

On February 13, 2010, the six NetQuakes instruments recorded an M 3.2 earthquake (fig. 5; note black triangles with the OK station designation). Using arrival times picked from the NetQuakes records in the distance range of 2-14 km from the epicenter, the new location (fig. 5; note red star with SLU designation) was about $9 \mathrm{~km}$ different from the initial NEIC location (fig. 5; red star with NEIC designation). The initial NEIC location was based on arrival-time picks from all ANSS and TA stations within $500 \mathrm{~km}$ of the earthquake; the closest Transportable Array stations (V34A and W34A, shown on figure 5 by black triangles) are within 30-40 km from the earthquake, while the closest ANSS backbone stations are about $150 \mathrm{~km}$ from the epicenter and off the map (fig. 5). Figure 5 does show the NEIC location (black star) from the M 3.8 earthquake of January 15, 2010, as well as the NEIC and SLU locations from the M 3.0 earthquake of February 15, 2010. (The M 3.8 earthquake of January 15 occurred before the NetQuakes instruments were deployed.) Both the M 3.8 and M 3.2 events show a systematic location bias of 8-10 km when using only the TA and existing ANSS stations and the AK135 velocity model. 


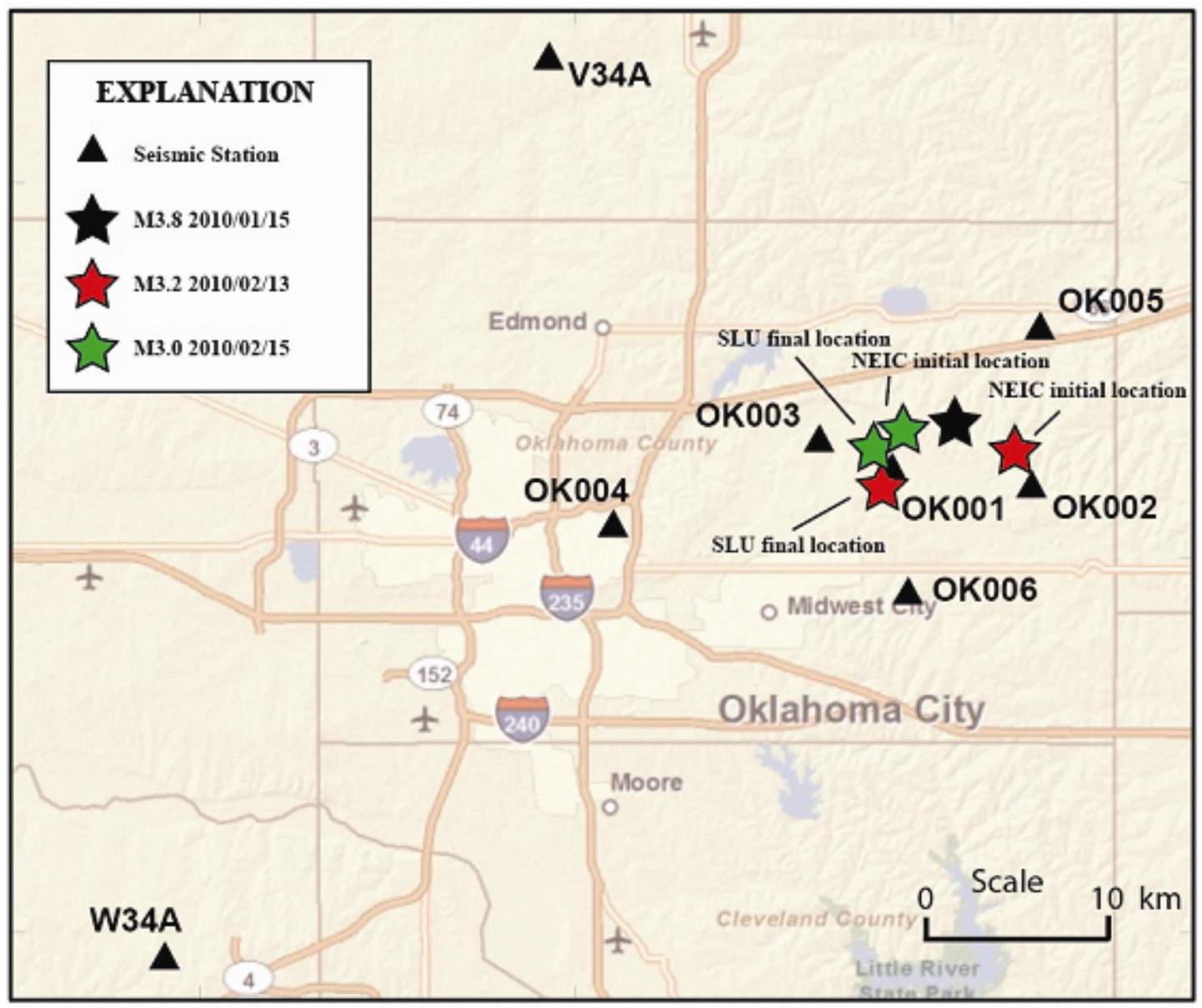

Figure 5. Map summarizing relative earthquake locations for three earthquakes from the 2009-2010 swarm near Oklahoma City, Oklahoma, determined first using only existing permanent Advanced National Seismic System (ANSS) and Transportable Array stations, and later including arrival-time information from temporarily deployed NetQuakes strong-motion recorders. Stations are denoted by black triangles; earthquake locations are denoted by stars.

Modeling both the M 3.2 and M 3.0 earthquakes of February 13 and 15, 2010 (figs. 5-6, respectively), showed the importance of on-scale, near-source observations of earthquakes for improved constraints on earthquake source parameters. In those cases, close stations mitigated the need for well-calibrated velocity models in order to produce accurate earthquake locations. Waveform modeling showed that modern accelerometer systems, such as the NetQuakes instruments, are capable of recording high-fidelity waveforms that can be used in estimations of earthquake moment magnitude, mechanism, and source depth. 
M3.2 2010/02/13 05:30 Oklahoma

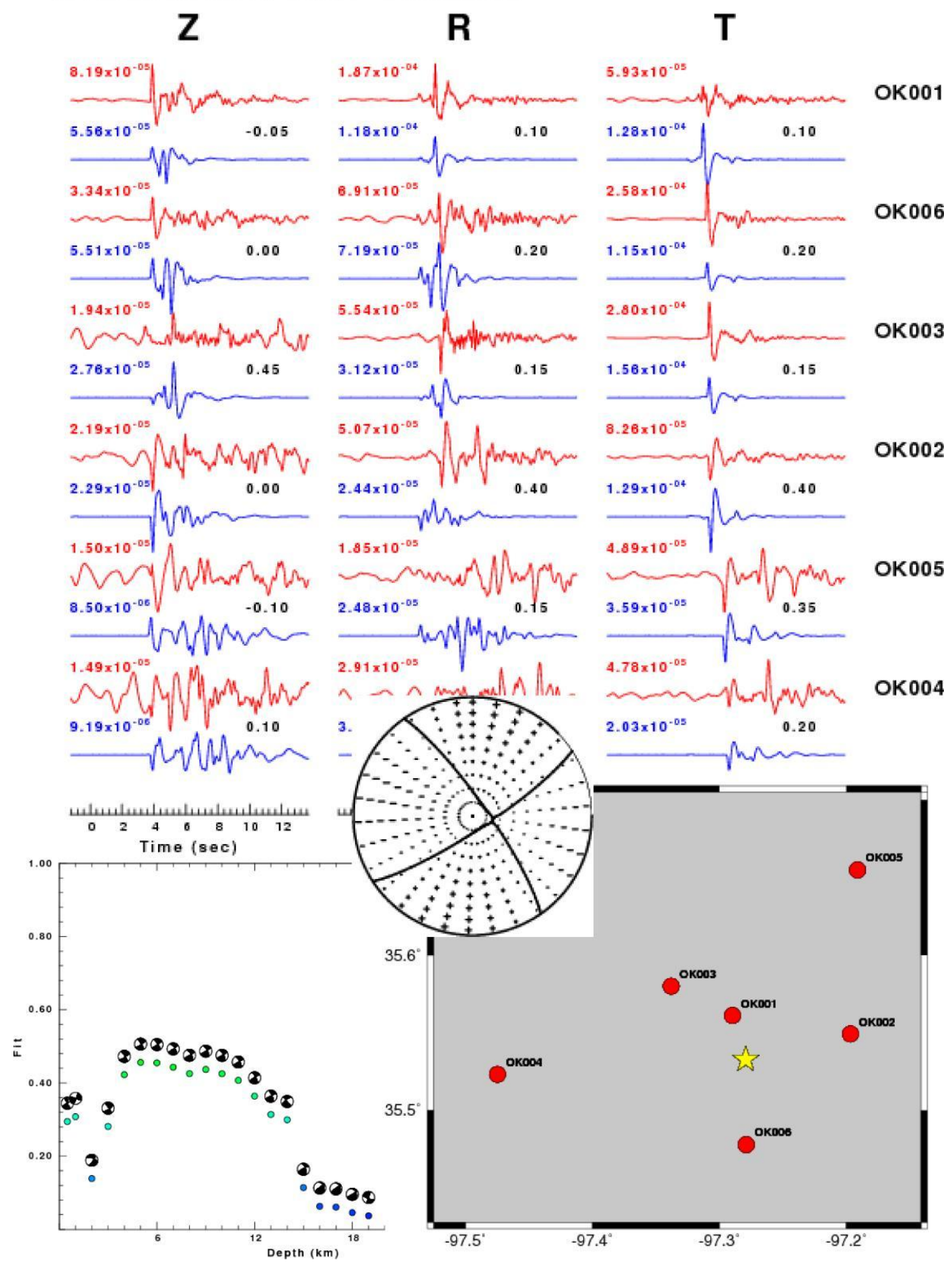

Figure 6. Regional moment tensor results for the M 3.2 February 13, 2010, Oklahoma earthquakes. The observed (red) and synthetic (blue) seismograms are shown for comparison for the best-fitting mechanism and moment magnitude. Also plotted are the best-fitting results for depths ranging from $0.5-19 \mathrm{~km}$. The location of the earthquake (yellow star) relative to the NetQuakes instruments (red circles) also is shown for comparison. 
This swarm demonstrated to the USGS that systems like NetQuakes can be integrated into network operations rapidly and easily. By deploying such systems in areas of increased seismic activity, ANSS gains the ability to document earthquake source parameters much more thoroughly and accurately. In addition, such action would enable USGS scientists to capture a larger event of interest and subsequently use the improved source information to understand and model regional propagation and attenuation better than when events were observed only with more-distant stations. In the Oklahoma swarm, the USGS determined that NetQuakes instruments record relatively smallmagnitude earthquakes ( $\mathrm{M}<3)$ quite well to distances over $20 \mathrm{~km}$ and can be used in waveformmodeling procedures and similarly sophisticated procedures. The National Earthquake Information Center (NEIC) and USGS-Menlo Park implemented procedures to acquire NetQuakes waveforms automatically from the field units and integrate them in NEIC and Menlo Park acquisition and processing systems, to ensure quick integration of the time series for standard processing (that is, determination of event location, magnitude, and regional moment tensors) and for inclusion in impact-assessment products such as ShakeMap.

\section{Illinois Case Study: February 10, 2010, M 3.8 Northern Illinois Earthquake}

At 03:59 local time on Wednesday, February 10, 2010, an M 3.8 earthquake occurred about $69 \mathrm{~km}$ west of Chicago (fig. 7), within $100 \mathrm{~km}$ of five nuclear powerplants (NPPs). The earthquake was strong enough to be felt by more than two million people, of whom more than 18,000 reported what they felt (fig. 8) through the USGS Community Internet Intensity Map web interface ("Did you feel it?"). The earthquake occurred in a part of the CEUS lacking dense seismic networks but which is in an area of interest to USNRC because of its proximity to critical facilities. Because the closest regional seismic station was more than $170 \mathrm{~km}$ from the earthquake, the initial NEIC location was about $9 \mathrm{~km}$ from the final calculated location. An improved location was possible only through inclusion of a $P$-wave arrival time from an Incorporated Research Institutions for Seismology (IRIS) educational seismograph-program seismogram from Elgin, Illinois, at a distance of some $12 \mathrm{~km}$ from the epicenter. While it was fortunate to have a station close by, the station itself is uncalibrated and useful therefore only for locating the earthquake, not for modeling detailed source properties. In addition, no information was available about the state-of-health of the instrument; quality checks on its timekeeping accuracy also were unavailable. Quality-control steps subsequently taken for the Elgin-station waveform were based on e-mail exchanges with the science teacher at the hosting institution; no post-event calibration was possible. Although USGS seismologists were able to confirm that timing likely was accurate, that experience illustrates that mission-critical operations require well-developed command-and-control procedures for station calibration and operation, which are well established ANSS processes. While it is difficult to factor the occurrence of earthquakes outside expected source regions, had seismographs been installed and operated under ANSS protocols at or near the Illinois critical facilities, ANSS would have had immediate access to first-arrival time information to provide a better initial earthquake location as well as direct observation of waveforms and ground-shaking metrics needed for USGS ShakeMap and ShakeCast ("ShakeMap Broadcast") notification to the USNRC and to critical-facilities operators (fig. 9). Such information could be very valuable if a larger event were to occur that could require assessment of magnitude-distance criteria used to determine plant actions.

Lessons learned from the Illinois earthquake include the need for better regional velocity models to improve earthquake-location procedures in areas with only sparse regional network coverage, plus real-time monitoring of critical facilities across the region. Precise timing, ground- 
shaking measurements, and waveform data at or near those northern Illinois facilities would have improved the accuracy of time-critical earthquake information for USNRC operations and provided new data of engineering interest to the USGS and USNRC mitigation programs.

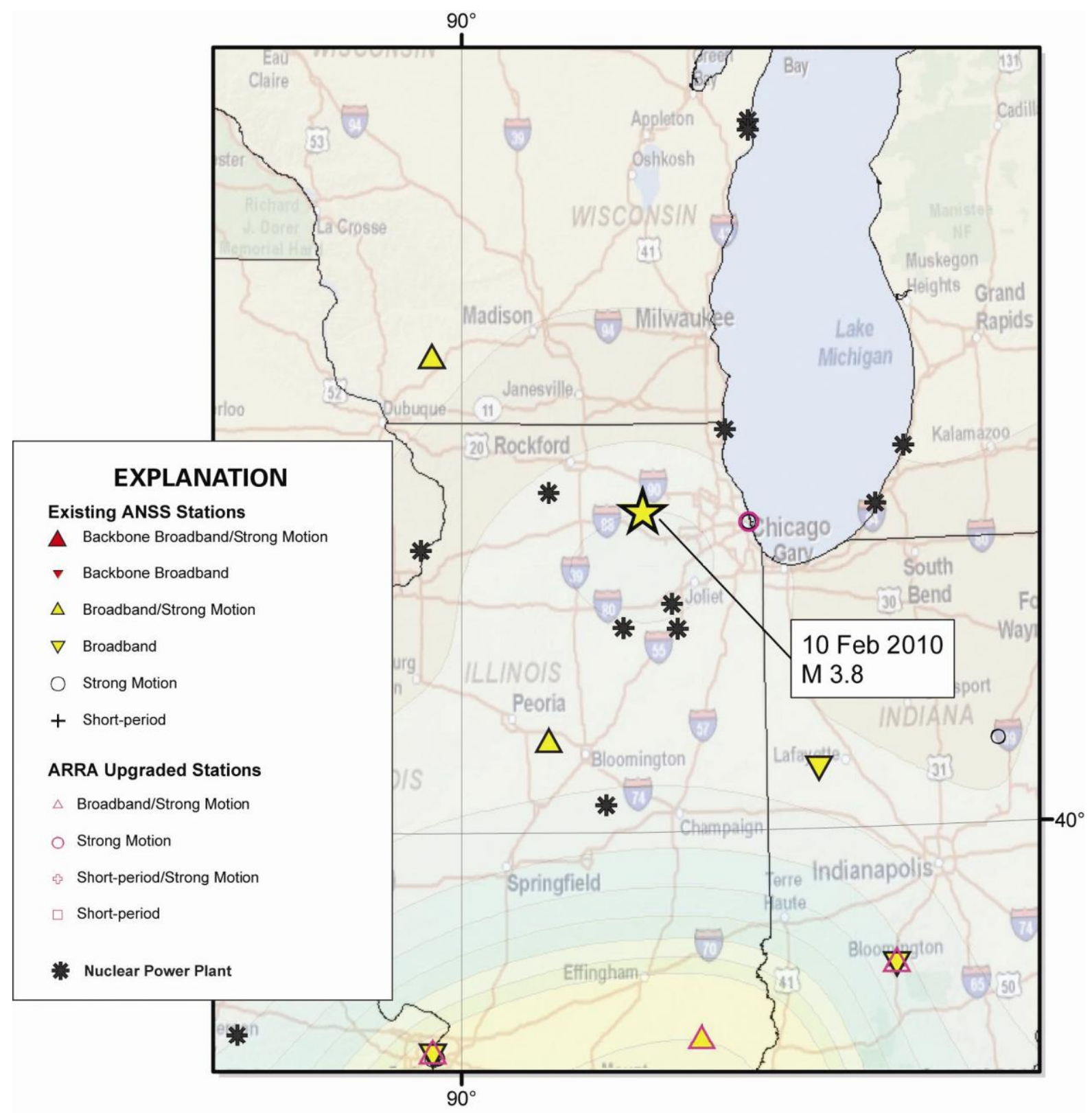

Figure 7. Map showing location of the February 10, 2010, M 3.8 northern Illinois earthquake (yellow star). Also shown are the locations of the nuclear powerplants (NPPs, black stars) and Advanced National Seismic System (ANSS) seismic stations (triangles and circles) in the region. 
USGS Community Internet Intensity Map

ILLINOIS

Feb 102010 03:59:35 local 41.9688N 88.4977W M3.8 Depth: 10 km ID:us2010snay

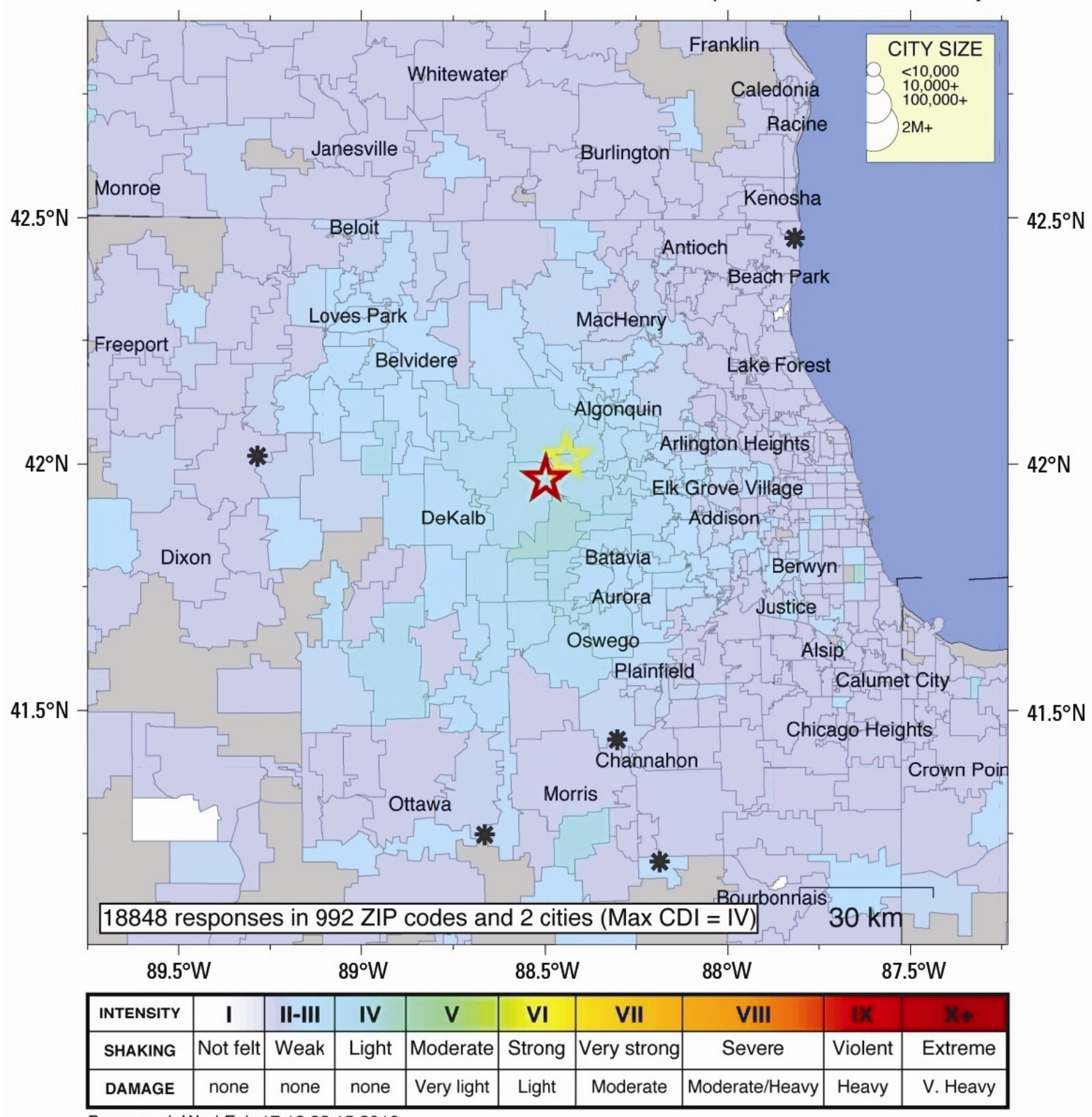

Processed: Wed Feb 17 18:35:15 2010

Figure 8. Map showing the macroseismic intensities near Elgin, Illinois, reported from the February 2010 earthquake based on web-based entries from the community-internet intensities project. Also shown is a comparison between the initial National Earthquake Information Center (NEIC) location (yellow star) using only Advanced National Seismic System stations and the final location (red star), which used a P-wave arrival time from a high-school seismograph station operating in Elgin, III. (approximately $9 \mathrm{~km}$ from the epicenter). 


\section{ShakeCast Event: Magnitude 3.8}

ShakeMap (Unnamed Event) Version 2

Event Location: ILLINOIS

Event Time: 2010-02-10 09:59:33

Generated at 2010-02-10 13:13:20

Reported by: Server ID = 1000, DNS = gldcast.cr.usgs.gov

\section{Damage Summary}

Number of NUCLEAR Facility Reported: 5

Max Value: MMI: 2; Acceleration: (not measured)

Number of Reports of Likely Damage: 0

Number of Reports of Possible Damage: 0

Number of Reports of Unlikely Damage: 5

\section{FACILITY Damage Estimates from ShakeMap}

\begin{tabular}{|l|l|l|l|l|}
\hline Nuclear Power Plant & Damage Level & Metric & Value & Exceedance Ratio \\
\hline Dresden, Morris, IL & Unlikely & MMI & 2 & 0.250 \\
\hline Braidwood, Braceville, IL & Unlikely & MMI & 1.82 & 0.205 \\
\hline Zion, Zion, IL & Unlikely & MMI & 1.71 & 0.177 \\
\hline Byron, Byron, IL & Unlikely & MMI & 1.11 & 0.028 \\
\hline LaSalle, Marseilles, IL & Unlikely & MMI & 1 & 0.000 \\
\hline
\end{tabular}

[END]

Figure 9. Output from ShakeCast showing estimated seismic intensities at the five closest nuclear powerplants (NPPs) to the February 10, 2010, M 3.8 northern Illinois earthquake, based on modeled predictions of ground shaking. The MMI (Modified Mercalli Intensity) values for this earthquake were well below nominal damage thresholds (Exceedance ratios well below 1.0). 


\section{Future Improvements to Advanced National Seismic System and Regional Seismic Networks}

It is implicit in the strategy that data from new or upgraded seismic stations in the CEUS initiated through coordinated USNRC and USGS efforts be available readily to all parties for production of routine monitoring datasets (such as earthquake catalogs), including automated preparation for use in USGS ShakeMap/ShakeCast response applications relevant to operation of critical facilities. Similarly, time series of engineering interest must be processed under a defined quality-assurance program and distributed for public access by the ANSS National Strong Motion Project. All station metadata must be fully documented and distributed through standard ANSS mechanisms (including anonymous ftp, station web-services, or station-client server applications), while all time series will be archived at an ANSS-supported waveform repository.

Future instrumentation upgrades and evaluations to be considered:

- Prioritized installation of at least 38 Class A or B strong-motion systems within active CEUS source zones to improve characterization of earthquake parameters and collection of near-source ground-motion waveforms for studies of ground-motion attenuation and source scaling as well as for engineering applications.

- Prioritized installation of at least 62 Class A or B strong-motion systems at or near critical (nuclear) facilities to be used for emergency-response applications, site-response studies, and engineering.

- Coordinated deployment of aftershock monitoring systems for rapid characterization of earthquake sequences anywhere within the United States of importance to the USNRC mission, and in particular, in regions not adequately monitoring to lower magnitudes (typically less than M 2.5).

- Expansion of the number of broadband/strong-motion aftershock systems at the USGS Geological Hazards Science Center from 21 to 30 to be used in studies of special interest (for example, aftershock monitoring) and for detailed ambient-noise and Green's Function data generation for areas of interest (such as active source zones and near critical facilities).

While not discussed in detail here, both the USGS and USNRC are also interested in application of rotational-motion sensors in structural monitoring and in the near-field rupture zone. The USGS has purchased several strong-motion rotation sensors in order to evaluate response characteristics, field worthiness, and capabilities for addressing issues related to building deformation and rocking following significant earthquakes. This work will proceed with significant coordination with USNRC research staff.

The USGS has tried to quantify the minimum level of effort required to improve characterization of earthquake effects at sites of interest in the near-source region. Either additional monitoring of specific critical sites or of seismic source zones will improve the quantity, quality, and content of earthquake information products produced by the Advanced National Seismic System in support of the USNRC mission.

\section{Development of Rapid Delivery of Parametric Ground-Motion Data}

Situational awareness for potential future earthquake-induced shaking at nuclear powerplants and other critical facilities requires both proper instrumentation and source-parameter modeling and software for displaying and quantifying earthquake ground shaking relative to facilities of interest. ShakeCast (short for ShakeMap Broadcast) is a fully automated USGS system 
for delivering Advanced National Seismic System (ANSS)-generated ShakeMap products to critical users such as the USNRC (Lin and Wald, 2008). ShakeCast also is designed to deliver triggered notifications and tailored post-earthquake response products. Figure 10 provides an overview of the features and issues addressed by ShakeCast software.

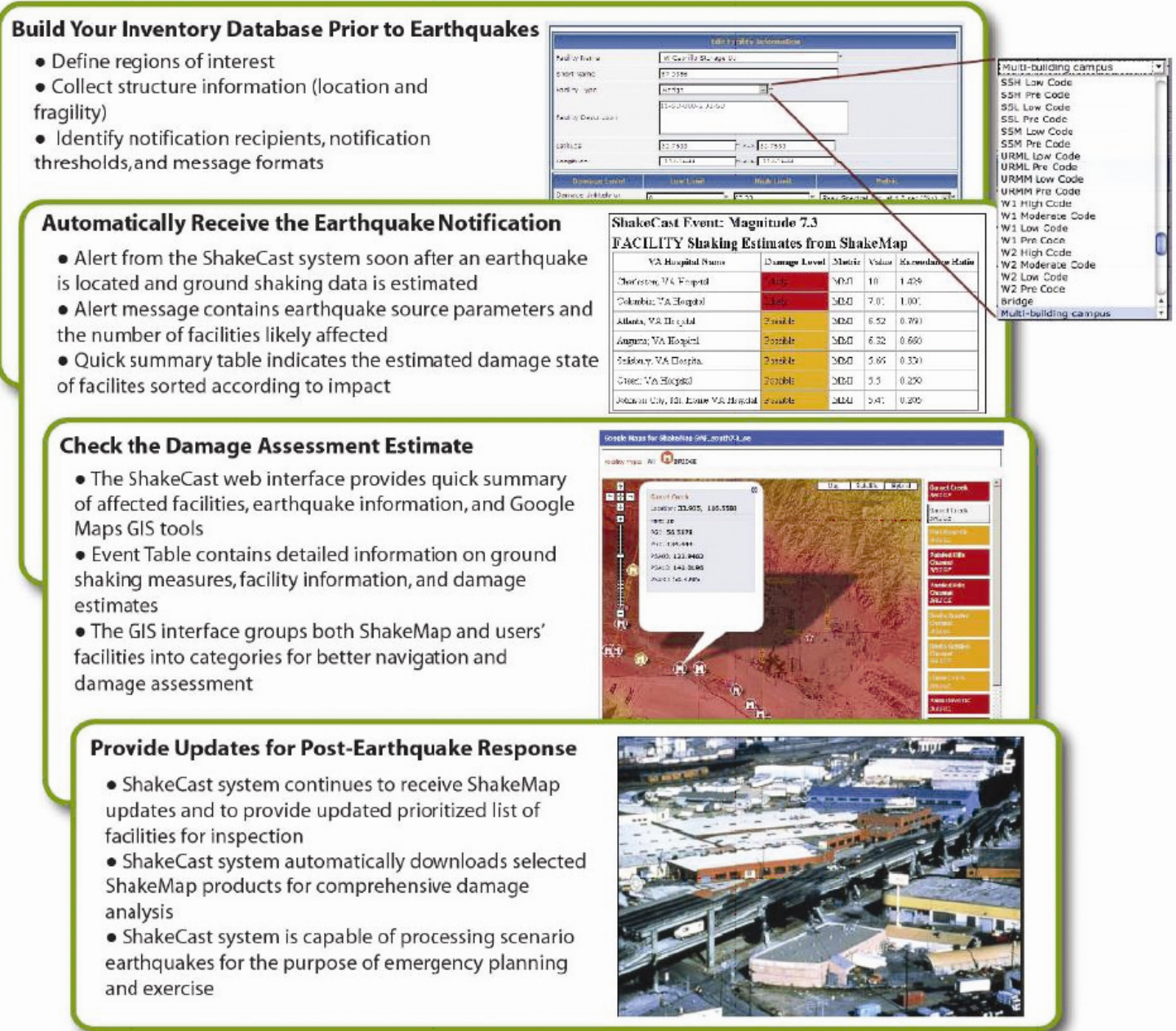

Figure 10. Overview of the ShakeCast system for quantifying and displaying earthquake ground-shaking information, from the user's perspective. 
ShakeMap is a well-established USGS-developed tool used to portray the location and spatial extent of potentially damaging shaking following an earthquake (ShakeMap accessed at the permanent URL http://earthquake.usgs.gov/shakemap/ (accessed 04/14/2011). ShakeMap is generated automatically for moderate and large earthquakes nationwide. It was developed and primarily is used for emergency response, loss estimation, and public information. For an informed response to a serious earthquake, however, critical facility operators such as the USNRC must go beyond just looking at ShakeMap and must use it to predict the likely extent and severity of impacts on the facilities they regulate. ShakeCast (a software application for automating ShakeMap delivery, U.S. Geological Survey, available at the permanent URL http://earthquake.usgs.gov/research/software/shakecast/ (accessed 04/14/2011) allows regulatory agencies such as the USNRC, utilities, transportation agencies, businesses, and other large organizations, ${ }^{1}$ to control and optimize the earthquake information they receive. With ShakeCast, the USNRC would automatically receive estimated shaking levels at nuclear plants and other critical facilities of interest, set thresholds for notification of damage states for each facility, and then automatically notify (by pager, cell phone, or email) specified persons within those organizations who are designated for response.

In addition to real-time notification, ShakeCast can generate and deliver scenario earthquakes useful for developing and practicing facility response plans (fig. 11). This capability allows users either to evaluate risks from probable earthquakes and to develop procedures for emergency response or to take mitigation actions. The application includes routine testing of the ShakeCast system, earthquake scenario exercises, and evaluation of performance and response under potential earthquake conditions. ShakeCast therefore allows planning exercises to be performed using the same notification tools available and in place for responding to a real earthquake.

\footnotetext{
${ }^{1}$ Examples of utilities and agencies currently using ShakeCast include the Los Angeles Unified School District; Caltrans, California Department of Transportation; California Department of Water Resources; Division of Homeland Security; Utah Department of Public Safety; Federal Emergency Management Agency; U.S. Department of Veterans Affairs; ImageCat, Inc.; and the International Atomic Energy Agency.
} 


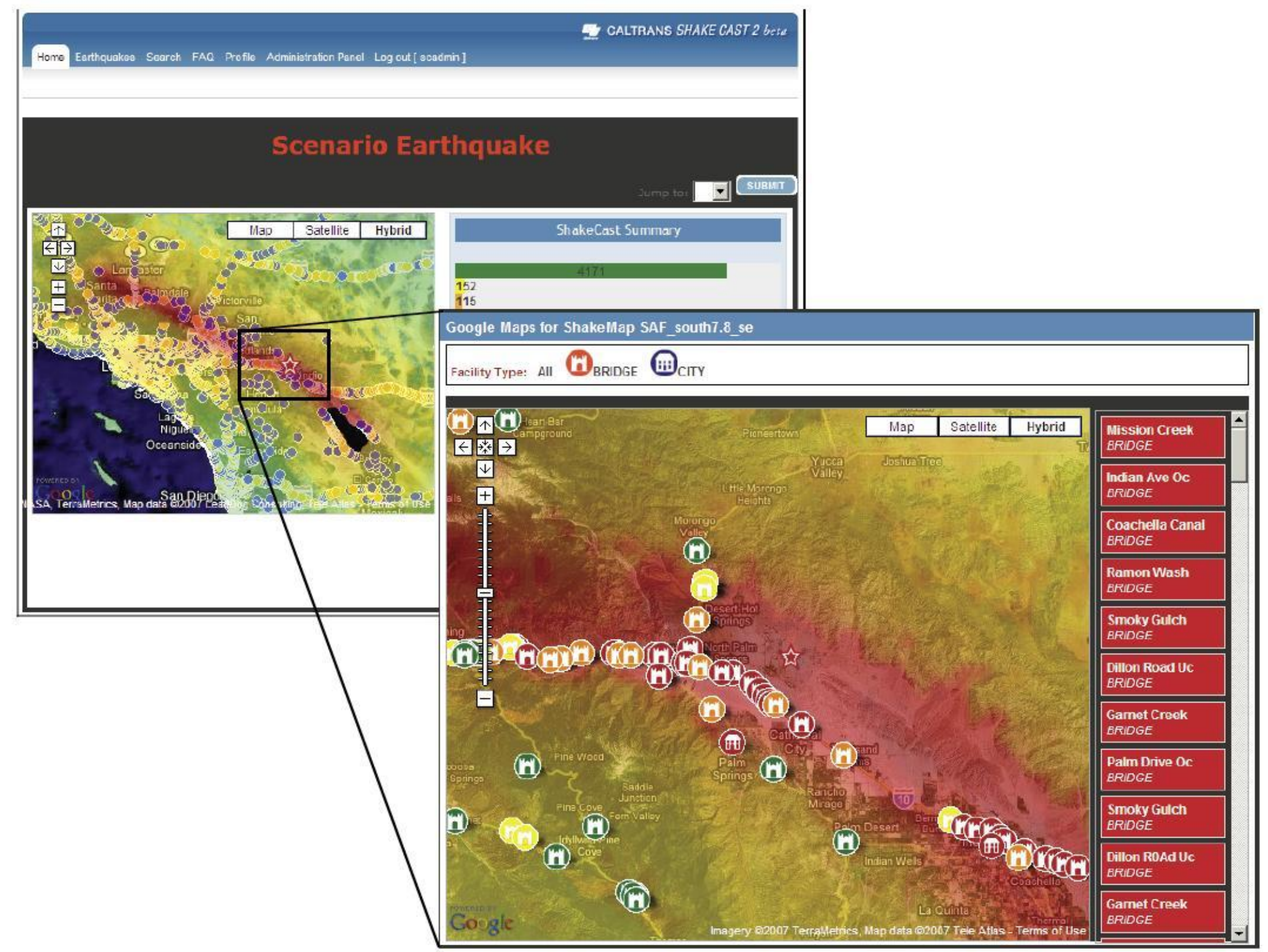

Figure 11. Example of ShakeCast information delivery from the M 7.8 southern San Andreas scenario earthquake used in the ShakeOut earthquake exercise from a prioritized list and map of Caltrans facilities displayed in the mapping mode of the ShakeCast client. (ShakeCast/ShakeMap software uses copyrighted Google, Inc., imagery as a base for presentation of seismic information. Copyright remains with Google, Inc.) 
An overview of ShakeCast capabilities and examples of user implementations can be found at http://earthquake.usgs.gov/research/software/shakecast/ (accessed 04/14/2011). Organizations typically download and install the ShakeCast software package on a hardened in-house computer system. The software is installed by an interactive script. Facility, vulnerability, and notification data are put in using import tools and simple, commaseparated (CSV) users' files. ShakeCast comes preconfigured ${ }^{2}$ but the USGS suggests a custom configuration for the USNRC. The ShakeCast web interface allows an administrator to access all functions of their local system; the USNRC will be able to manage its own contact information and notification preferences. ${ }^{3}$

The USGS suggests implementing ShakeCast in two steps: (1) complete an assessment of real-time tools and ShakeCast implementations already at USNRC; and (2) perform an optimized ShakeCast system implementation. The assessment step would consist of (a) determining the appropriate ANSS real-time products (ENS, CISN-Display, ShakeCast Prototype) for USNRC users with different responsibilities or at different locations; (b) holding a stakeholder workshop at either/both USGS and USNRC; and (c) developing a project plan ("white paper") and a timeline for accomplishing the plan. In the workshops, the following topics could be reviewed: case histories in the use of ShakeCast (Caltrans, Department of Water Resources, etc.); IT security and related IT issues; the potential for collection and use of site-specific ground-motion data; and project goals and timeline.

To implement the ShakeCast System at the USNRC, USGS would work with USNRC staff as so-called "critical users" to custom-harden ShakeCast and redesign the software subsystem as necessary for the USNRC application and to address ShakeCast RSS delivery speed and robustness. The USNRC would be provided with specific documentation for its critical operational environment. The USNRC would provide a list of facilities and vulnerabilities for ShakeCast configuration and develop its preferences for notifications and alert criteria. Over the longer term, the USGS would provide customer service support, ongoing training, IT interaction, and a support helpline.

Further research and development is needed to customize ShakeCast for USNRCspecific interests, including provision of ShakeMap operational support for the CEUS systems-backbone station parametric data from the ANSS regional nets; triggering; and inclusion of macroseismic data. A customized suite of ground-motion prediction equations is needed for CEUS ShakeMaps. In addition, the ShakeMap atlas needs to be expanded to include all historic events of USNRC interest, and USNRC-selected scenarios should be developed in ShakeCast as system tests and scenarios.

\footnotetext{
${ }^{2}$ Information Technology (IT) security is a primary concern for users requiring automatic electronic delivery of information. By taking advantage of standard Internet protocols, ShakeCast users avoid most typical corporate and government concerns and firewall limitations. By using Really Simple Syndication (RSS) and interval polling, users initiate all communications with the USGS web servers that host ShakeMap and retrieve selected products as a request rather than a "push." This RSS approach allows users to update software automatically under conditions of their own choosing.

${ }^{3}$ ShakeCast software is built upon open-source tools, providing standard, freely available software for all users, encouraging user improvements, and simplifying interfacing with existing users' response tools. ShakeCast uses the Apache Web server and PHP (Hypertext Preprocessor) for dynamic web content, MySQL for facility and notification databases, and is wrapped in Practical Extraction and Report Language (PERL) scripting. Exchange files are in Extensible Markup Language (XML) for standardized interfacing with web, geographic information system (GIS), spreadsheet, database, and other applications.
} 


\section{Summary}

Characterization of potential earthquake ground motions through enhanced seismic monitoring capabilities demonstrates important elements for the evaluation of seismic hazards at critical facilities. This report to the U.S. Nuclear Regulatory Commission-a Phase 2 report - focuses on evaluation and improvement of seismic monitoring capabilities in the central and eastern United States in support of future public safety and regulatory needs, particularly with respect to known seismic zones (such as the East Tennessee Seismic Zone, the New Madrid Fault Zone, the Charleston Seismic Zone, and others) and proximity to nuclear powerplant sites. The evaluation of monitoring capabilities is strengthened by the National Science Foundation Transportable Array, a large set of monitoring stations traversing the country in appraisal of seismicity, crustal structure, and active source zones. The American Recovery and Reinvestment Act has also provided a unique opportunity to improve monitoring capabilities through upgrades to networks of the USGS Advanced National Seismic System (ANSS) of monitoring stations. Conceptually, the USGS and other partners such as the USNRC can leverage their respective seismic hazards and mitigation activities by using ANSS as an effective national seismic-data collection, processing and distribution platform.

Within the central and eastern United States, the USGS suggests that improved seismic monitoring should include deployment of at least 38 new ANSS strong-motion stations in seismically active central and eastern United States earthquake source zones to improve seismic monitoring to address issues in the source region, as well as 62 new strongmotion stations specifically located near critical facilities such as nuclear powerplants to address issues of seismic wave propagation and site response in the vicinity of those sites. Key transportable-array stations should also be evaluated as potential permanent stations as part of ANSS regional seismic networks. Related objectives include expansion of seismic databases for ground-motion data to lower-magnitude events needed to address earthquake source characterization, attenuation, and propagation across the central and eastern United States, including implementation of improved USGS ShakeMap and ShakeCast tools for enhanced communication of earthquake intensity and characteristics to the USNRC and other critical facility operators to support rapid response and assessment activities. Network improvements also are considered through a mix of strong-motion systems, using moreexpensive high-resolution instruments in a complementary mix that includes lowerresolution, lower-cost units in culturally noisy urban environments to improve the density of strong-motion recordings in built-up areas; the higher-cost instruments can be placed for best monitoring of active seismic areas. Two case studies of actual earthquakes in Oklahoma and near Chicago attest to the value of the various data arrays and data-evaluation methods. These and other approaches further leverage the ARRA upgrades through governmental, university, national laboratory, and Canadian efforts. Because the USGS and regional partners operate monitoring networks under broad instrumentation, metadata, and dataexchange protocols, addition of new stations in the central and eastern United States is costeffective and relatively easy. Targeted upgrades to monitoring networks will provide data to reduce uncertainty in hazard estimation of low-probability events and improve confidence in seismic design. The strong-motion monitoring is an essential part of this long-term strategy.

These considerations of monitoring and data-handling support for enhancement of instrument upgrades (a mix of strong-motion stations) focused on seismically active zones and specifically on critical infrastructure such as nuclear powerplant sites. Such approaches 
improve characterization of earthquake parameters and collection of near-source groundmotion waveforms for studies of attenuation, scaling, and engineering applications. Improved capabilities and characterization of aftershock sequences and expansion of ground motion datasets is addressed by consideration of approaches to monitor adequately to lower magnitude(s) through rapid deployment of additional broadband and strong-motion monitoring systems housed at the USGS Geologic Hazards Science Center, and targeted studies of ambient noise in active source zones near critical facilities.

Finally, the report considers the near real-time situational awareness offered by proper instrumentation and source-parameter modeling, along with delivery of such analytical information to users in the nuclear powerplant community through use of USGS products such as ShakeCast. That automated system can provide rapid information to critical users such as the USNRC, covering details of an event and estimated damage assessment, along with updates based on aftershock events. The same system can be configured for use in realistic training scenarios for exercises in emergency planning and response.

\section{Acknowledgments}

Numerous collaborators provided input, ideas, or elements of text for this report. Because of the primary effort by the listed authors and the wide disparity of contributions as to size or significance, we have determined that the best way to acknowledge those contributions is by listing collaborators and affiliations as follow here. We are grateful for all contributions to our understanding of the task of enhancing and strengthening observations of seismic events with respect to safety at critical facilities such as nuclear powerplants. We also gratefully acknowledge assistance from the U.S. Nuclear Regulatory Commission through Interagency Joint Agreement JCN-N6184. 


\section{Contributors}

Leith, William

Principal Investigator

Benz, Harley

Co-principal Investigator

Herrmann, Robert

Principal Consultant

Ebel, John

Evans, John

Fletcher, Joe

Frankel, Arthur

Kim, Won-Young

McNamara, Daniel

Nigbor, Robert

Owens, Thomas

Wald, David

Withers, Mitch

Woodward, Robert
ANSS Coordinator

U.S. Geological Survey

Reston, VA 20192

ANSS Technical Manager

U.S. Geological Survey

Denver, CO 80225

Professor of Earth Sciences

St. Louis University

St. Louis, MO 63103

Professor of Earth Science

Boston College

Boston, MA 02467

Research Geophysicist

U.S. Geological Survey

Menlo Park, CA 94025

Research Geophysicist

U.S. Geological Survey

Menlo Park, CA 94025

Research Geophysicist U.S. Geological Survey

Seattle, WA 98195

Research Geophysicist Lamont-Doherty Earth Observatory of Columbia University

Palisades, NY 10964

Research Geophysicist

U.S. Geological Survey

Denver, CO 80225

Research Civil Engineer

University of California at Los Angeles

Westwood, CA 90024

Professor of Earth Science

University of South Carolina

Columbia, SC 29208

Research Geophysicist

U.S. Geological Survey

Denver, CO 80225

Research Geophysicist

Center for Earthquake Research and

Information of the University of Memphis

Memphis, TN 38152

Incorporated Research Institutions for Seismology Washington, D.C. 20005 


\section{Selected References}

Lin, K.-W., and Wald, D.J., 2008, SHAKECAST users manual: U.S. Geological Survey OpenFile Report 2008-1158, 90 p.

U.S. Nuclear Regulatory Commission, 2008, Nuclear Regulatory Commission Seismic Research Program Plan, Fiscal Years 2008-2011: U.S. Nuclear Regulatory Commission, January 2008, 48 p.

U. S. Geological Survey, 1999, An assessment of seismic monitoring in the United StatesRequirement for an Advanced National Seismic System: U.S. Geological Survey Circular $1188,55 \mathrm{p}$.

U. S. Geological Survey, 2009, ANSS—Advanced National Seismic System: U.S.

Geological Survey, unpaginated, accessed 04/14/2011, at

http://earthquake.usgs.gov/research/monitoring/anss (for published performance standards).

Publishing support provided by:

Denver Publishing Service Center

For more information concerning this publication, contact:

Center Director, USGS Geologic Hazards Science Center

Box 25046, Mail Stop 966

Denver, C080225

(303) 273-8579

Or visit Geologic Hazards Science Center Web site at:

http://geohazards.cr.usgs.gov/ 
